\title{
ROLE OF GENETICS AND SOCIAL CONNECTEDNESS ON RESILIENCE: A COMPARISON BETWEEN VARSITY ATHLETES AND NON-ATHLETES
}

by

\section{Samantha Coates}

A thesis submitted to the Department of Neuroscience in partial fulfillment of the requirement for the degree of

\author{
Master of Science \\ In \\ Neuroscience \\ Carleton University \\ Ottawa, Ontario
}

(C) 2016

Samantha Coates 


\begin{abstract}
Resilience generally refers to an individual's ability to overcome illness or to cope with trauma or adversity. There appears to be great variability in this regard, possibly being attributable to life events, social designations, personality traits and genetic factors. The goal of the present study was to examine the relationship between early life trauma, social connectedness and psychological well-being and to investigate the role of a neuropeptide Y (NPY) polymorphism (rs 16147) among varsity athletes. Carleton University varsity athletes and nonvarsity athlete students $(N=284)$ completed questionnaires and provided saliva samples for genotyping. It was found that there was a relationship between early life trauma and diminished psychological well-being. This relationship was mediated by social connectedness, which was then further moderated by NPY genotypes. Specifically, individuals with the non-protective, polymorphism (GG genotype) were more influenced by social connectedness in relation to enhanced psychological well-being when compared to individuals carrying the A allele. In addition, an individual's participation in varsity athletics moderated the relationship between early life trauma, social connectedness and psychological well-being, in that athletes were less likely to have diminished social connectedness following trauma compared to non-athletes. Furthermore, among non-athletes, individuals carrying the AA genotype had higher levels of psychological well-being compared to G carriers, whereas among athletes, the GG individuals had the higher levels of psychological well-being. These findings suggest that among individuals that had experienced trauma, the GG genotype might be linked to resilience and higher levels of well-being, in a highly social environmental.
\end{abstract}




\section{Acknowledgments}

I would first like to thank my supervisor, Dr. Hymie Anisman for his invaluable guidance, mentorship and support throughout this thesis. I have learned more from Hymie than things taught in a book, and will be always grateful. I would also like to thank my committee members, Dr. Alfonzo Abizaid and Dr. Michael Hildebrand for their time and input into my thesis. I would like to give my sincerest thanks to the PhD's of the lab for their guidance and leadership, as well as their friendship. I am so thankful to the friends that I have made over the course of my time at Carleton, you have helped me in more ways than you know and I have learned so much from you. Lastly, words cannot express my appreciation for my family, especially my parents, friends and boyfriend who had to listen to me endlessly. I would never have made it without their unconditional love and encouragement and to them I dedicate this thesis. 


\section{Table of Contents}

Title Page

Abstract

Acknowledgment

Table of Content

List of Tables

List of Figures

List of Appendices

Introduction

Resilient Traits

Early Life Experiences

Social Connectedness

Stress Neurobiology and Neuropeptide Y

Genetic variations of Neuropeptide $Y$

Resilience in Varsity Athletes

Hypotheses

Methods

Participants

Procedures

Measures

Background Information

Resilience

Connectedness

Early Life Trauma

Depression

Genotyping

Statistical Analysis

Results 


\section{List of Tables}

Table 1. Allele distributions for polymorphisms.

Table 2. Mean scores of Ryff's Psychological Well-Being subscales and total among NPY genotypes (AA, AG and GG), including t-test results for differences in levels among genotypes.

Table 3. Mean scores of Ryff's Psychological Well-Being subscales and total across condition (Athlete and Control), including t-test results for differences in levels among genotypes.

Table 4. Pearson Correlations depicting relations between trauma (general, emotional and physical), social connectedness and all well-being sub scales. $(n=283)$. Note: $* * p<.001 * p<.05$. 


\section{List of Figures}

Figure 1. Moderated mediation analysis examining the relation between early life trauma and psychological well- being through social connectedness and mediations of condition and genotype.

Figure 2. Changes in Psychological Well-Being as a function of condition and genotype. There was a significant difference in psychological well- being across genotypes within both groups, however the relationship was reversed based on condition. Note: $* * p<.001 * p<.05$. 


\section{List of Appendices}

Appendix A: Recruitment Notice $\quad 40$

Appendix B: Informed Consent $\quad 42$

Appendix C: Written Debriefing 47

Appendix D: Background Information $\quad 49$

Appendix E: Ryff's Well-Being Scales $\quad 54$

Appendix F: Social Connectedness Scale $\quad 60$

Appendix G: Early Life Trauma Inventory $\quad 62$

Appendix H: Beck Depression Inventory $\quad 65$ 


\section{Introduction}

An individual's ability to cope with stressors likely determines the long-term effects that adversity will have. Importantly, not every person that encounters trauma develops pathology later in life. Individuals react differently to stressors, and even more complicated is that a single individual may react differently to various types of a stressors (Leipold \& Greve, 2009). Resilience is currently being defined principally as the successful adaptation to severe adversity, trauma or other forms of stress (McEwen, 2003; Charney, 2004; Rutter, 2006; Russo et al., 2012). Resilience is therefore, not simply an absence of pathology but in fact it is an active adaptation to stress. However, individuals who are resilient in one aspect of their life, such as academics, may not be similarly resilient in other components of their life, like close relationships. Differences in an individual's biology, psychological and social distinctions likely allow for the development of resilience.

Resilience in the face of stressful events is an active adaptive process that encompasses a number of personal traits that allow an individual to better handle events without the threat of long-term consequences. Many traits that are seen to be important in resilience are likewise viewed as important in the development psychological well-being (Ryff, 1989). These traits may include optimism, active and strong coping skills, cognitive flexibility, self-awareness, a strong internal locus of control and a constellation of other psychosocial factors. In terms of psychological well-being, these include personal growth, purpose in life, environmental mastery, autonomy and self-acceptance (Ryff, 1989). In addition, resilient individuals are more likely to surround themselves with other resilient individuals and have grown up with resilient role models (Dumont, Widom \& Czaja, 2007; Banyard \& Williams, 2007). With respects to psychological well-being, this can be identified as positive relationships with others (Ryff, 
1989). Research has yet to determine whether an individual needs to possess all of these traits to be resilient, and which of these characteristics are particularly relevant.

In addition to social factors and personality traits, environment and life experiences likely play a large role in the development or loss of resiliency. Early childhood trauma and neglect contribute to the development of non-resilient adults, especially when close relationships in adolescence are lacking. Additionally, social connectedness is seen to act as a buffer to the long term effects of early life trauma, even as early life trauma leads to an apparent sense of loneliness and individuals have difficulty feeling as though they belong (Lee \& Robbins, 1995). However, there is considerable variability in this regard. It is possible that genetic factors through interactions and predispositions to various characteristics, coping mechanisms and psychopathologies contribute to the poor resilience.

Many neurochemicals are involved in stress resilience and coping, and the hormone neuropeptide Y (NPY) has been gaining attention as an important factor in resilience. This hormone is involved in many human behaviors, primarily those involved in the stress response as a stress moderator and resilience factor. Of particular interest with respects to the NPY system is a polymorphism on the promoter region, $r$ 16147:A>G With the $\mathrm{G}$ variant believed to cause a decrease in neuropeptide Y plasma levels, increased stress symptoms, and the likelihood at developing an anxiety disorder or depression.

Given these findings, the present investigation was meant to examine (1) the impact of social connectedness on resilience (2) genetic factors that may affect resilience and (3) whether elite athletes are characteristically and/or genetically more resilient than a control population. 


\section{$\underline{\text { Resilient Traits }}$}

Resilience in the face of stressful events encompasses a number of behaviors, prosocial characteristics, and personality traits that allow for better management of stressors without the threat of long-term consequences. Resilient individuals are generally considered as having high positive emotionality. Positive emotions have been examined in relation to primary appraisal during stressful situations, with positive affect leading to benefits from the stressful event, as opposed to negative outcomes that would generally arise when faced with a stressor (Folkman \& Moskowitz, 2000). In addition, positive affect also allows recovery from the subjectively appraised detrimental effects of stressors (Campbell-Sills, Cohan \& Stein, 2007). Optimism, as an example, is associated with increased well-being and psychological health as well physiological changes otherwise elicited by a stressor (Affleck \& Tennan, 1996; Folkman \& Moskowitz, 2000). Optimists tend not to react to adversity with techniques such as avoidance and helplessness and are less likely to suffer from anhedonia and depression (Carver et al., 2010; Warner et al., 2012). In addition, optimists tend to have a strong sense of purpose in life (Ryff, 1989). Similarly, having a strong internal locus of control as well as high self-esteem and purpose in life aids in implementing positive methods of managing stressors (Simeon et al., 2007; Alim et al., 2008). Self-esteem is strongly correlated with characteristics that generally increase resilience, such as strong coping, persistence and even happiness (Baumeister et al., 2003). Likewise, intelligence, planning, self-regulation and physical exercise all have been linked to the development of resiliency (Pruessner et al., 2005; Collishaw et al., 2007). Prosocial behaviors, like altruism, humour and social relationships and interactions are similarly important in becoming resilient (Bleuler, 1984; Vaillant, 1992; Horman- Stahl \& Peterson, 1996;

Southwick et al., 2005; Ozbay et al., 2008; Leontopoulou, 2010; Southwick \& Charney, 2012) 
It is clear that many individual characteristics alter the ability to cope with stress and particular personality traits are more closely linked to resilience than others. Therein this regard, a strong negative relationship exists between neuroticism and resilience (Campbell-Sills, Cohan \& Stein, 2006; Collishaw et al., 2007; Shi, 2015). Neuroticism is the tendency to frequently experience negative emotions like anger and anxiety as well as generally being emotionally unstable, and this may lead to greater vulnerability to psychopathologies later in life. In contrast to neuroticism, extroversion and conscientiousness are positively related to resiliency (CampbellSills et al., 2006; Shi, 2015). Extraverts usually display positive emotions and are characteristically social. Likewise, individuals who are conscientious are typically dependable and disciplined in their actions. Extraversion, in addition to increasing the resilience, also tends to lead individuals to positive affect, increased capacity for closeness, and improved social interactions and relationships, allowing them to have a strong social support system and to develop better methods of dealing with stress (Campbell-Sills et al., 2006).

It remains unclear, however, whether an individual needs to possess all of these traits to be resilient or if some traits are more relevant than others in this regard. Different methods of coping are also likely to alter an individual's ability to cope with stressors, in so far as individuals who use task-oriented (i.e., problem-focused) coping are more resilient compared to those who use emotion-oriented coping. Interestingly, individuals that are considered conscientious, an important trait that contributes to resilience, generally use task-oriented coping, additionally promoting resilience (Campbell-Sills, Cohan \& Stein, 2007). It seems, as well, that resilience varies across different types of stressors (i.e., academic or relationhips) and that cognitive flexibility is important in responding appropriately to various stressors (Bonanno et al., 
2004). Cognitive flexibility, like resilience, requires a positive outlook on challenges and failures.

\section{Early Life Experiences}

Not all individuals that are faced with trauma develop pathologies; environment and experience likely affect these outcomes. Childhood trauma greatly alters the development of a well-adjusted adult and is one of the leading risk factors for developing depression later in life (Campbell-Sills, Cohan and Stein, 2006; Collishaw et al., 2007). For an individual to be resilient to trauma in adulthood, they need to have experienced mild trauma during childhood, however, proper social support and strong role models are necessary for a child to learn resilience when faced with trauma (Banyard \& Williams, 2007). When looking at the role of resilience in attenuating later psychological symptoms, individuals who reported having high levels of emotional neglect but were found to be high in resilience had the least amount of psychiatric symptoms, even when compared to individuals who reported low levels of emotional neglect and high resilience (Campbell-Sills et al., 2006). Likewise, individuals that reported moderate to severe abuse and were high in resiliency had better psychosocial functioning when compared to individuals that had no psychiatric symptoms and had suffered no abuse in their lifetime (Collishaw et al., 2007). It appears that as opposed to simple recovery from adversity, resilience is a successful adaptation following trauma or a stressor (Bonanno, 2004). Effective coping following trauma at an early age leads to personal growth allowing the individual to be more resistant to minor stressors later in life and thus have lower levels of psychological symptoms (Bonanno, 2004; Campell-Sills et al., 2006). 
Effective coping early in life to trauma largely affects the development of resilience, but for this to occur children and adolescents require good social relationships and a sense of community throughout life (Banyard \& Williams, 2007; DuMont, et al., 2007). When comparing abuse victims, just under half reported no psychopathology later in life due to increased levels of resilience (Collishaw et al., 2007). It was noted that not only did the resilient group report having good relationships with at least one parent; they also reported having quality relationships in adolescence and adulthood with peers (Banyard \& Williams, 2007; Collishaw et al., 2007).

\section{$\underline{\text { Social Connectedness }}$}

Social connectedness appears to buffer against trauma and adversity (Rozanski et al., 1999; Fontana et al., 1989). Social support may modify genetic and environment vulnerabilities (Ozbay et al., 2007). Research has shown a strong relationship between social interactions and depression in that joining even one social group can greatly reduce depressive relapse (Cruyws et al., 2013, Southwick et al., 2005). This relationship is also strengthened with each additional group joined (Cryuwys et al., 2013). It is believed that social connectedness may enhance an individuals' ability to positively interpret stressors and enhance as well as protect psychological well-being. Social connectedness can be used as therapy to combat existing depression, but is most effective as a tool to combat depression as an individual is on a trajectory towards it (Cruwys et al., 2013; Paykel, 1994). Additionally, high connectedness preceding a trauma has been seen to confer resilience to adversity (Dignam, 2008; Resik, 2001). In contrast, loneliness is an important contributor to the development of depression. It may be that social connected individuals are in fact more resilient than individuals that are not, as resilient individuals appear to be more open to social connectedness (Feder et al., 2009) and have more positive relations with others (Herman-Stahl \& Peterson, 1996). 
Social connectedness is well seen as a method to increase psychological well-being; however it can be negatively affected by trauma (Dumont \& Provost, 1998). Early life trauma has been seen to lead to diminished levels of social connectedness (Lee \& Robbins, 1995, Dignam et al., 2008). It is possible that following early life trauma, an individual may have difficulty registering that they do have social support. However, it may also be that following trauma, there is a decrease in seeking social connectedness (Lee \& Robbins, 1995; Dumont \& Provost, 1998). Moreover, individuals may have difficulty forming long-term personal relationships and develop a lack of belongingness in their social groups (Lee \& Robbins, 1995).

\section{Stress Neurobiology of Neuropeptide Y}

Early life trauma does not just alter psychosocial traits, but can also lead to alterations in brain function. Stressors cause a cascade of endocrine responses that lead to behavioral changes in order to adapt to a new environment. The hypothalamic-pituitary-adrenal (HPA) axis plays a large role in this stress response. Exposure to stress leads to a cascade of responses resulting in the release of cortisol, a stress induced glucocorticoid. Cortisol has many important functions, and dysregulation of the HPA system can be harmful. Hyperactivity of the HPA axis can lead to increased levels of cortisol, which if sustained can result in hippocampal cell loss (McEwen, 1999). Diminished hippocampal volume has been associated with depression, including characteristics, such as diminished self-esteem (McEwen, 1999; Pruessner et al., 2004). Limbic system changes may also include decreased amygdala reactivity when faced with negative stimuli (Janssen et al., 2007; Dannlowski et al., 2012).

In addition to these factors, neuropeptide Y (NPY) has been gaining attention as an important hormone in stress resilience (Zhou, 2008). Neuropeptide Y is a 36 amino acid 
neuropeptide that is highly concentrated in the forebrain, the limbic system and the brain stem, with high levels of receptors being present in the cortex, hippocampus, amygdala, which may be involved in reward and fear (Charney, 2004; Broekman et al., 2006; Medina, 2009). Decreases in NPY have been shown to affect limbic system functioning by possibly increasing amygdala and hippocampal activity in relation to threat facial expressions (Domschke et al., 2010). Diminished levels of NPY may also play a role in decreased opioid recruitment following stressors, resulting in increased anxiety (Zhou et al., 2008; Sah, 2013). Neuropeptide Y has also been implicated in the regulation of appetite, energy balance, reward, stress appraisal, anxiety, fear, learning and memory as well sympathetic activities, such as changes in blood pressure (Broekman et al., 2006; Medina et al., 2009; Sommer et al., 2010).

Neuropeptide Y has been linked to HPA axis functioning, and may have an anxiolytic effect, likely through its counteraction of corticotropin releasing hormone (CRH) (Sajdyk et al., 2004; Witt et al., 2011; Wu et al., 2011) specifically in the amygdala, hippocampus, hypothalamus and the locus coeruleus (Sajdyk et al., 2004). In extensive military training, soldiers with higher levels of NPY exhibit better behavioral performance and are better at handling stressors than individuals with low NPY levels (Morgan et al., 2002). In addition, retired combat veterans with higher levels of neuropeptide Y were less likely to develop PTSD when compared to combat veterans with lower levels (Yehunda et al., 2006; Sah et al., 2009). In essence, NPY promoted resilience and decreased levels of distress (Morgan, 2000, 2002; Yehuda, 2006). Animal studies have similarly indicated that NPY may act o buffer the impact of stressors For instance, the administration of NPY intranasally increased stress resilience in rats (Sajdyk, 2008), being able to attenuate and even reverse symptoms (Serova, 2013). 
Neuropeptide Y levels are not only linked to anxiety disorders, but also depression and suicidality. Decreased levels of NPY have been found in patients that have attempted suicide as well as in brain tissues of individuals that died by suicide (Widdowsen et al., 1992). It is difficult to know whether past experiences, including those that led to depression, affected levels of NPY or whether there was a genetic predisposition that altered NPY production.

\section{Genetic Variations of Neuropeptide Y}

Genetic variations of NPY have been found to predict levels of resilience in response to a stressor (Zhou et al., 2008; Zhang et al., 2012). A specific single nucleotide polymorphism (SNP) on the promotor region, rs16147:A $>\mathrm{G}$ influences levels of NPY expression as well as protein levels, although environmental factors certainly alter NPY levels as well (Sommer et al., 2010). The majority of research looking at the anxiolytic effects of NPY has found that the A variant appears to be protective against psychopathology following adversity. However, there appears to be conflicting results when observing which variant results in a diminished level of NPY mRNA expression. This may be explained due to the influence of environment on NPY production. At rest, carriers of the G variant appear to produce lower levels of NPY compared to homozygous A carriers whereas under stress, the G allele carriers appear to produce more NPY (Sommer et al., 2010). As rest, the G variant appears to result in a 30\% reduction in NPY mRNA expression (Zhou et al., 2008). However, it has been repeatedly replicated that an A to G substitution leads to an increased risk at developing depression or generalized anxiety disorder following adversity (Heilig et al., 2004; Domschke et al., 2010; Sommer et al., 2010). In comparing normal and depressed groups, there is a significant increase in G-alleles present (Heilig et al., 2004). 
Moreover, SNP alterations are also linked to the treatment of depression, where the Gvariant lead to slower and impaired response to anti-depressants (Domschke et al., 2010). This may be due to an effect that rs 16147 variations may have on HPA functioning, and particularly levels of adrenocorticotropic hormone (ACTH) and cortisol. Individuals homozygous for the A allele appear to have lower levels of ACTH and cortisol released following a stressor if they experienced high levels of adversity as a child, however AA carriers showed opposite results if they did not experience childhood trauma (Amstadter et al., 2010; Witt et al., 2011).

\section{$\underline{\text { Resilience in Varsity Athletes }}$}

Elite athletes represent a population of particular interest in the study of resilience. Elite athletes are an example of a resilient group. Athletic performance at an elite level requires more than just physical ability and toughness, as there is an important psychological component to becoming among the best in a sport. At high levels of sport, a principle difference between those that are successful and those that are not is often due to their increased control over psychological factors, including motivation, resilience and emotion (Wiser \& Thiel, 2012). In addition to dealing with substantial pressure to succeed, athletes invest great amounts of cognitive energy to their sport over years of practice and competition (Schaal et al., 2011). With increasing demands to win, athletes must either be already resilient or learn coping mechanisms that allow them to thrive under this pressure to succeed. A 2014 study found that athletes that were found to be "mentally hardy" embodied characteristics like determination, constancy, selfbelief and positive cognition (Wiser \& Thiel, 2014). Even with increased 'mental toughness', elite athletes are not immune to psychopathology. In fact, gender-based differences that exist in the general population with respect to psychopathology exist equally among athletes; particularly in relation to generalized anxiety disorder (Schaal et al., 2011). 
Physical activity and exercise are also linked to positive effects on well-being, including mood and self-esteem (Harris et al., 2006). Interestingly, exercise is also linked to increased neurogenesis as well as enhanced production of neuropeptide $Y$, which could be due to genetic differences in athlete populations (Bjornebekk et al., 2005).

Participation in athletics adds additional social support. Social activities, sports included, alter individuals' personality development as well as changes in their socialization or levels of support seeking (Holland \& Andre, 1987; Dumont \& Provost, 1998). 


\section{Hypotheses}

In view of the presumed links between personality traits, behaviours, genetics, and resilience, the purpose of the present investigation is to examine whether relationships exist between these factors among elite athletes. It is hypothesized that:

1. Social connectedness is highly implicated in resilience

2. Neuropeptide Y polymorphisms will be predictive of whether or not individuals are more resilient during stressful times

3. The athlete population will differ from the normal population in terms of resilience 


\section{Methods}

\section{$\underline{\text { Participants }}$}

Approximately 400 male and female undergraduate students were recruited using the online SONA system at Carleton University as well as through their varsity sport teams at Carleton University (Appendix A). Due to the genetic basis of the study, of the 421 recruited participants, $286(\mathrm{M}$ age $=20.34, \mathrm{SD}=5.213)$ were of White/Euro-Caucasian decent, which will be used for further analysis. This sample comprised $69 \%$ female $(n=197, \mathrm{M}$ age $=19.76$, SD $=4.065)$ and $31 \%$ male $(n=89, \mathrm{M}$ age $=21.63, \mathrm{SD}=6.984)$.

\section{$\underline{\text { Procedure }}$}

The study protocol was approved by the Psychology Research Ethics Board at Carleton University. Participant data was collected between fall 2015 and winter 2016. Upon receipt of informed consent (Appendix B), participants were given a set of questionnaires for completion and provided a saliva sample. Upon completion, participants were debriefed (Appendix C) and issued $1.50 \%$ experimental credit through the SONA system or a $5 \$$ Tim Horton's gift card.

\section{$\underline{\text { Measures }}$}

Background Information. Participants provided demographic details, medical history, and athletic history (Appendix D).

Psychological Resilience. Psychological well-being can be defined as the combination of subjective positive states (e.g., happiness) and functioning with optimal effectiveness in individual and social life (e.g.. life satisfaction), as well as health-related behaviours (Deci \& Ryan, 2008; Ryff, 1989). This was measured using Ryff's Well-Being Scales (Clarke, Marshall, Ryff \& Wheaton, 2001; Appendix G) which consists of six 14-item subscales designed to 
measure various dimensions of psychological well-being; self-acceptance (Cronbach $\alpha$ of 0.82 ), environmental mastery (Cronbach $\alpha$ of 0.82 ), positive relations with others (Cronbach $\alpha$ of 0.88 ), personal growth (Cronbach $\alpha$ of 0.88 ), purpose in life (Cronbach $\alpha$ of 0.87 ), and autonomy (Cronbach $\alpha$ of 0.58). Respondents select from a 6-point scale ranging from "Strongly Disagree" (1) to "Strongly Agree" (6), all of which are highly implicated in psychological resilience. Scores are summed across the 14 items of each subscale resulting in a total between 14 and 84 . Psychological well-being scores have shown a negative association with depressive symptoms (Ryff, 1989; Ryff \& Keyes, 1995; Wells et al., 1989) and displayed positive correlations with resilience measures (Sagone \& De Caroli, 2014; Souri \& Hasanirad, 2011). Thus, it has been suggested that well-being may be useful as an adjunctive index of resilience (Galatzer-Levy, Burton, \& Bonanno, 2012; Ryff, 1989).

Social Connectedness. The psychological sense of belonging was measured using the Social Connectedness Scale - Revised (20-item SCS-R; Lee, Draper, \& Lee, 2001; Appendix H) Participants select responses based on a 6-point scale ranging from "Strongly Disagree" (1) to "Strongly Agree" (6) and a total score ranging from 20 to 120 is calculated by summing across all items with a higher score indicative of greater social connectedness. The SCS had a Cronbach $\alpha$ of 0.94).

Early Life Trauma. Early life trauma was assessed using the Traumatic Life Events Questionaire (ELTI; Bremmer, Bolus \& Mayer, 2007; Appendix L) is a 27-item measure assessing various types of early life events including general trauma (Cronbach $\alpha$ of 0.62 ), physical abuse (Cronbach $\alpha$ of 0.59), emotional abuse (Cronbach $\alpha$ of 0.87 ) and sexual abuse (Cronbach $\alpha$ of 0.458 ). The ELTI asks respondents to indicate whether or not they have experienced the trauma, and the number of times in which they did. Higher scores indicate a 
greater number of early life trauma's experienced by respondents. The total Cronbach $\alpha$ of ELTI is 0.79 .

Depressive Symptoms. The intensity of depressive symptoms was assessed using the Beck Depression Inventory (BDI-21 item version; Beck, Ward, Mendelson, Mock \& Erbaugh, 1961; Appendix O). The BDI is a widely used multiple-choice style self-administered questionnaire to assess the intensity of depression in clinical and normal individuals. For each item, individuals pick the best statement that describes their depressive symptomology. Lower numbers (e.g., 0) indicate a lower intensity of depressive symptoms, while higher numbers (e.g., 2 and 3) are related to greater intensity. The intensity of depression is computed by summing the scores across all 21 items resulting in scores ranging from $0-63$. The score indicates the overall intensity of depression: 0-9 indicates minimal depression, 10-18 indicates mild-moderate depression, 19-29 indicates moderate-severe depression and 30+ indicates severe depression. The Cronbach's $\alpha$ for the BDI is 0.872 .

\section{Genotyping}

NORGEN Saliva DNA Isolation Kits were used to collect saliva samples $(\sim 2 \mathrm{ml})$ for subsequent isolation and purification of DNA from the preserved samples, which were then stored at $-80^{\circ} \mathrm{C}$. Steps for collection, preservation, and isolation were followed as outlined in the kits' instructions. All samples were diluted in ultrapure water to a concentration of $20 \mathrm{ng} / \mu 1$ and measured to $35 \mu 1$ prior to shipment. DNA samples were sent to the McGill University and Génome Québec Innovation Centre in Montreal, Quebec for SNP genotyping using Sequenom ${ }^{\circledR}$ iPLEX ${ }^{\circledR}$ Gold Genotyping Technology. 
Often, discernable differences in genotype distribution have been observed across ethnicities. Genetic distribution of the NPY SNP, rs16147, varies across demographics, as an example, African populations have a much larger frequency of A alleles (0.72) compared to G, whereas those of European decent have a smaller frequency of the A allele (0.39) compared to the $\mathrm{G}$ allele (Sherry et al., 2001). Therefore, a homogenous ethic sample was used and only Caucasian participants were used for analysis involving genotype. The genotype distributions for Caucasian participants (Table 1) met Hardy-Weinberg Equilibrium expectations, $X^{2}=0.096 p=$ 0.526. Genotypes for two participants were unable to be determined and thus, were excluded from all analyses conducted using genotype.

Table 1. Allele distributions for polymorphisms.

\begin{tabular}{|c|c|c|c|}
\hline & AA & $\mathrm{AG}$ & GG \\
\hline NPY rs16147 & 80 & 139 & 65 \\
\hline
\end{tabular}

$\underline{\text { Statistical Analysis }}$

Statistical analyses were performed using SPSS Statistics Software for Windows 18.0 (SPSS Science, Chicago, IL, USA). For all analysis, standardized scores were used and statistical significance was determined at $\mathrm{p}<0.05$ (two-tailed). Correlation analyses were performed to examine the relationships between early life trauma, social connectedness and psychological well-being. Differences between early life trauma, social connectedness, well-being and genetics were assessed through analysis of variance (ANOVA) followed by Bonferroni corrected $t$ - tests to compare between individual groups. In addition, hierarchical regression analyses was conducted to determine whether early life traumatic experiences were related to well-being, and whether these relationships occurred through social connectedness and the significant moderations were following up using a web utility for simple slopes (Preacher, Curran \& Bauer, 
2006). Moderated mediations with NPY genotype variations and athletic ability were analyzed using bootstrapping procedures and confidence intervals based on 5000 resamples (Preacher, Rucker \& Hayes, 2007). 


\section{Results}

Psychological well-being, reflected by Ryff scores did not differ significantly across NPY genotypes (see Table 2). Indeed, t tests comparing the GG individuals to the pooled AG and AA genotype, indicated that these groups did not differ significantly from one another, $t_{(282)}=-.669$, $p=.163$. This was consistent within the subscales of well-being of the Ryff's well-being scale (see Table 2).

Table 2. Mean scores of Ryff's Psychological Well-Being subscales and total among NPY genotypes (AA, AG and GG), including t-test results for differences in levels among genotypes.

\begin{tabular}{|l|l|l|l|l|l|}
\hline & \multicolumn{3}{|c|}{ Mean Score } & \multicolumn{1}{c|}{$t$} & $p$ \\
\hline & AA & AG & GG & & \\
\hline Ryff's Psychological Well-being & $63.70(.942)$ & $61.78(.664)$ & $63.07(.849)$ & -.669 & .163 \\
\hline Environmental Mastery & $4.37(.080)$ & $4.12(.054)$ & $4.20(.093)$ & .004 & .009 \\
\hline Purpose in Life & $4.57(.076)$ & $4.44(.059)$ & $4.54(.065)$ & -.673 & .158 \\
\hline Self-Acceptance & $4.51(.091)$ & $4.36(0.78)$ & $4.50(.121)$ & -.748 & .074 \\
\hline Positive Relations with Others & $4.73(.095)$ & $4.45(.074)$ & $4.62(.097)$ & -.732 & .591 \\
\hline Personal Growth & $5.09(.078)$ & $5.07(.057)$ & $5.07(.039)$ & .048 & .799 \\
\hline Autonomy & $4.00(.081)$ & $4.06(.066)$ & $4.11(.072)$ & -.708 & .863 \\
\hline
\end{tabular}

Early life trauma scores also did not vary based on genotype, for the total score $t_{(282)}=$ $.932 p=.171$, as well as for trauma subscales, including physical trauma $t_{(282)}=1.028, p=.090$ and emotional trauma $t_{(282)}=-.968, p=.173$, but differed with respect to general trauma scores, $t_{(282)}=-2.138, p=.020$. Sexual trauma was infrequent and did not differ between groups. Lastly, genotype-related differences were not reported with respect to social connectedness, $t_{(282)}=$ $1.318, p=.794$.

Athletes and non-athlete controls did not differ in levels of well-being $(M=64.52, S E=$ $.553 ; M=61.63, S E=.729), t_{(282)}=-3.078, p=.792$ (see Table 2). Moreover, these groups did not 
statistically differ on any of the subscales of well-being, other than positive relations with others, (Table 3); however, as university athletics generally comprise a 'team' component, this is not surprising. Early life trauma scores did not differ between conditions with respect to early life physical trauma $t_{(282)}=-.752, p=.264$, general trauma $t_{(282)}=1.636, p=.156$ and emotional trauma $t_{(282)}=1.011, p=.085$. Lastly, social connectedness, was close, but not significantly different between athletes and controls $t_{(282)}=-3.381, p=.065$.

Table 3. Mean scores of Ryff's Psychological Well-Being subscales and total across condition (Athlete and Control), including t-test results for differences in levels among genotypes.

\begin{tabular}{|l|l|l|l|l|}
\hline & \multicolumn{2}{|c|}{ Absolute Score } & \multicolumn{1}{c|}{$t$} & \multicolumn{1}{c|}{$p$} \\
\hline & \multicolumn{1}{|c|}{ Athlete } & \multicolumn{1}{c|}{ Control } & & \\
\hline Ryff's Psychological Well-being & $64.52(.729)$ & $61.63(.554)$ & -3.078 & .792 \\
\hline Environmental Mastery & $4.32(.071)$ & $4.14(.051)$ & -2.085 & .916 \\
\hline Purpose in Life & $4.55(.062)$ & $4.47(.048)$ & -.981 & .235 \\
\hline Self-Acceptance & $4.64(.103)$ & $4.33(.063)$ & -2.714 & .651 \\
\hline Positive Relations with Others & $4.82(.076)$ & $4.43(.063)$ & -3.682 & .029 \\
\hline Personal Growth & $5.17(.063)$ & $5.03(.049)$ & -1.648 & .585 \\
\hline Autonomy & $4.18(0.079)$ & $4.00(.049)$ & -2.021 & .447 \\
\hline
\end{tabular}

Correlational analyses were performed with respect to trauma, social connectedness and psychological well-being. Bivariate correlation analyses indicated that trauma, in general, was negatively related to both social connectedness as well as each subscale of well-being (Table 4). In this respect, emotional trauma was prominently related to social connectedness, as well as overall well-being. Predictably, all subscales of psychological well-being were positively related to social connectedness (Table 4). 
Table 4. Pearson Correlations depicting relations between trauma (general, emotional and physical), social connectedness and all well-being sub scales. $(n=283)$. Note: $* * p<.001 * p<.05$.

\begin{tabular}{|c|c|c|c|c|c|c|c|c|c|c|}
\hline Situation & 1. & 2. & 3. & 4. & 5. & 6. & 7. & 8. & 9. & 10. \\
\hline 1. General Trauma & - & & & & & & & & & \\
\hline 2. Emotional Trauma & $.453^{* *}$ & - & & & & & & & & \\
\hline 3. Physical Trauma & $.359^{* *}$ & $.430^{* *}$ & - & & & & & & & \\
\hline 4. Social Connectedness & -.096 & $-.259 * *$ & -.023 & - & & & & & & \\
\hline 5. Purpose in Life & .012 & $-.171 * *$ & $-.134 *$ & $.435^{* *}$ & - & & & & & \\
\hline 6. Self-Acceptance & $-.162^{* *}$ & $-.291 * *$ & -.097 & $.589 * *$ & $.613^{* *}$ & - & & & & \\
\hline 7. Relationship with Others & -.111 & $-.253 * *$ & -.064 & $.810^{* *}$ & $.428^{* *}$ & $.575^{* *}$ & - & & & \\
\hline 8. Personal Growth & .010 & -.041 & .013 & $.329^{* *}$ & $.554^{* *}$ & $.456^{* *}$ & $.339^{* *}$ & - & & \\
\hline 9. Environmental Mastery & -.070 & $-.166^{* *}$ & -.067 & $.517^{* *}$ & $.538^{* *}$ & $.583^{* *}$ & $.472^{* * *}$ & $.336^{* *}$ & - & \\
\hline 10. Autonomy & .078 & -.013 & .021 & $.144^{*}$ & $.239 * *$ & $.401^{* *}$ & $.165^{* *}$ & $.220^{* *}$ & $.341^{* *}$ & - \\
\hline
\end{tabular}

The relation between early life emotional trauma and psychological well-being were highly significant, $R^{2}=.23, F(1,284)=16.127, p<.001$. Additionally, social connectedness was related early life trauma, $R^{2}=.26, F(1,284)=20.291, p<.001$ and to well-being $R^{2}=.458, F(1$, $284)=240.28, p<001$. The possible moderating effect of genotype was then investigated in terms of the relationship between early life emotional trauma and social connectedness with levels of psychological well-being.

To examine the possible interaction between trauma, social connectedness and levels of psychological well-being with NPY genotypes, a hierarchical linear regression was conducted. Genotype and trauma were entered on the first step, followed by the Genotype $\mathrm{x}$ Trauma interaction on the second step. The moderating role of the NPY genotype on the relation between emotional early life trauma was not found to be significant $R^{2}=0.0019, \Delta F(1,280)=.56, p=$ .4529. A second hierarchical linear regression was performed in which genotype was entered on the first step together with social connectedness. In the second step, the Genotype $\mathrm{x}$ Connectedness interaction was entered. The moderating role of NPY genotype on the relation between social connectedness and well-being was found to be significant $R^{2}=.0094, \Delta F(1$, $280)=4.9520, p=.0269$. A third hierarchical linear regression was conducted, investigating the 
moderating effect of NPY genotype on the relationship between early life trauma and social connectedness but this was also not found to be significant.

It was of interest to investigate potential pathways through which early life trauma may influence psychological well-being. Emotional trauma was strongly correlated to social connectedness and well-being, $R^{2}=.981, p<0.001$, and was thus assessed as a possible mediator through which trauma predicted levels of well-being. A mediation analysis was conducted, using bootstrapping techniques based on 5000 resamples to determine $95 \%$ confidence intervals (Preacher and Hayes, 2013). The mediated effect of connectedness in the relation between emotional trauma and well-being was significant (95\% CI $\{-.28,-.10\})$, but upon entering social connectedness as mediator, the original significant relationship of early life trauma and wellbeing disappeared. It was further examined whether this mediated relationship was moderated by the NPY genotype. Once again, genotype was pooled so that the AA and AG were compared with the mutated GG allele. Moderated mediation analyses using bootstrapping procedures and confidence intervals based on 5000 resamples showed that the NPY genotype moderated the mediating role of social connectedness in the relationship between emotional trauma and psychological well-being, $R^{2}=.48, F(4,279)=69.13, p<.001$ (Figure 1). Specifically, the relation between trauma and levels of well-being was mediated by social connectedness to a stronger degree for GG carriers than the AA/AG genotypes.

It was of additional interest to examine the influence of being a high performing athlete on psychological well-being. Much like with genotype, being part of the athlete group had a moderating effect on the mediating role of social connectedness between emotional trauma and well-being. In this case, however, it was found that the athlete vs control condition moderated the relationship between trauma and perception of social connectedness, $R^{2}=.48, F(4,279)=69.13$, 
$p<.001$ (Figure 1). Specifically, being an elite athlete was accompanied by individuals seeking more social connectedness than the control group.

This model (Figure 1) is shown looking at the effect on overall psychological well-being. As previously mentioned there are several subscales, of which personal growth $R^{2}=.13, F(4$, $278)=10.01, p<.001$, self-acceptance $R^{2}=.38, F(4,279)=43.49, p<.001$, and environmental mastery $R^{2}=.29, F(4,278)=28.36, p<.001$, are all found to be significant when looking at the mediating effect of social connectedness and moderating effects of condition and Genotype.

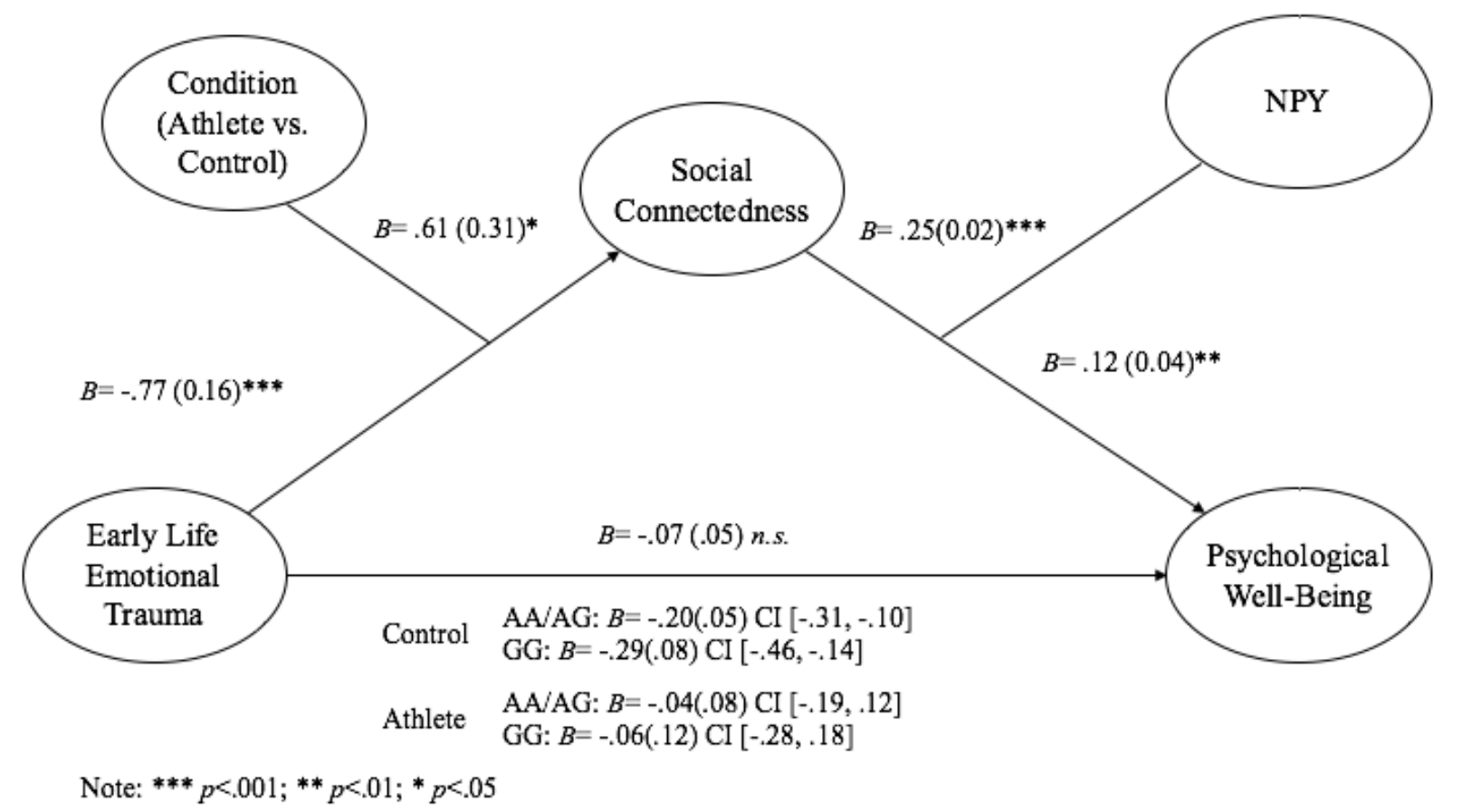

Figure 1. Moderated mediation analysis examining the relation between early life trauma and psychological well-being through social connectedness and mediations of condition and genotype.

To test the hypothesis that well-being varies as a function of group (athlete or control) and NPY genotypes, an ANOVA was used to examine these relationships. The analysis revealed that well-being varied as a function of the Genotype $\mathrm{x}$ Athletic condition interaction, $F(2,284)=$ $7.037, p=.001$. Follow-up tests confirmed that in the non-athletes, well-being was greater among 
those carrying the AA genotype than in the other groups. Curiously, among athletes, The GG carriers seemed to have greater levels of well-being than did the AA or AG genotypes (Figure 2). This relationship was significant among most subscales of the Ryff's Well-Being Scales, autonomy was nearing significance but personal growth and purpose in life were found to be insignificant.

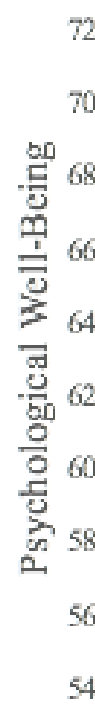

72

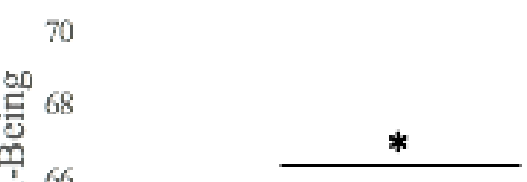

64

62

56

54
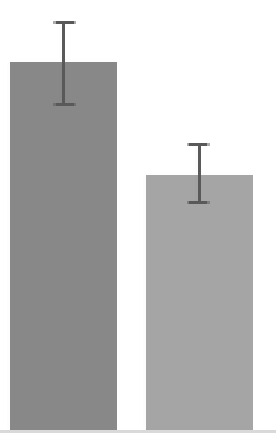

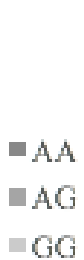

$\mathrm{GG}$

Control

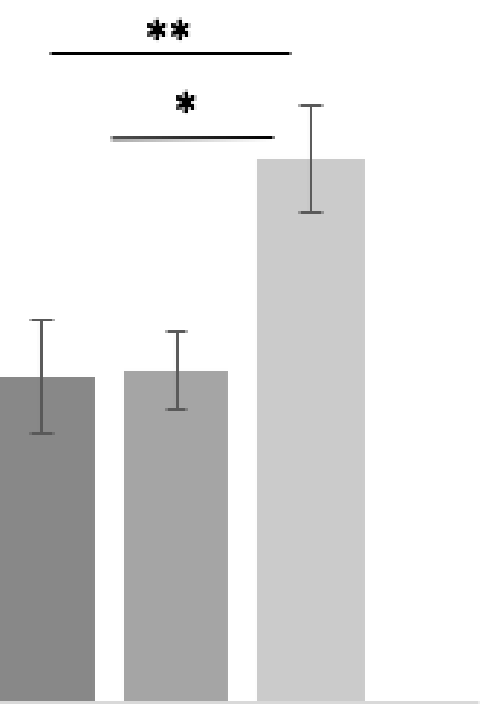

Athlete

Figure 2. Changes in Psychological Well-Being as a function of condition and genotype. There was a significant difference in psychological well-being across genotypes within both groups, however the relationship was reversed based on condition. Note: $* * p<.001 * p<.05$. 


\section{Discussion}

Trauma has a strong positive relationship with current and future depression and a negative relationship with well-being (Campbell-Sills, Cohan and Stein, 2006; Collishaw et al., 2007; Wingo et al., 2010). However, not all individuals who experience trauma develop mental illness later in life, and it appears that some individuals are more resilient in the capacity to overcome illness or to deal with stressors. Psychological resilience may be fostered by multiple factors. As previously mentioned, resilience encompasses many personality characteristics, including optimism, strong coping skills, motivation, locus of control, self-confidence and secure attachment. Moreover, social connectedness has been seen to impact well-being, as it buffers against trauma (Resik, 2005; Dignam, 2008; Cruwys et al., 2013) despite trauma potentially undermining connectedness (Lee \& Robbins, 1995; Dumont \& Provost, 1998).

The present study revealed that the relationship between early life emotional trauma and psychological well-being was mediated by social connectedness. Consistent with earlier reports (Campbell-Sills, Cohan and Stein, 2006; Collishaw et al., 2007; Ozbay et al., 2007; Bonanno et al., 2008; Wingo et al., 2010), there was a significant negative interaction between early life emotional trauma and overall psychological well-being. However, this link varied among individuals in relation to levels of depression or anxiety. In considering the possible pathways through which early life trauma alters psychological well-being, as previously reported (Campbell-Sills, Cohan and Stein, 2006; Collishaw et al., 2007), it appeared that early life trauma was accompanied by decreased social connectedness, which served as a mediator between early life-trauma and psychological well-being.

In keeping with reports that NPY might contribute to psychological well-being, resilience, measured using the Ryff's Scale of Psychological Well-Being, revealed that increased 
levels of early life trauma were related to decreases in psychological well-being. This scale encompasses the key characteristics of resilience (Ryff, 1989), including self-acceptance, locus of control and secure attachment. However, it is not necessarily the case that these components of resilience are sub served by the same psychosocial or neurobiological underpinnings.

Consistent with this perspective, it was observed that a single nucleotide polymorphism rs 16147 for the gene encoding for neuropeptide Y moderated the link between social connectedness and psychological well-being. Furthermore, levels of psychological well-being varied as a function of athletic group to which individuals belonged and genotype. As previously observed (Sommer et al., 2010), among students who were not varsity athletes, those carrying the G mutated allele had lower levels of well-being than did individuals carrying the AA alleles. However, among the varsity athletes), this relationship was not evident, and instead well-being was most closely linked to the GG genotype.

\section{Moderating Effects of Genotype}

As hypothesized, the association between early life trauma and psychological well-being, or resilience, was mediated by social connectedness. Additionally, the relationship between social connectedness and psychological well-being was moderated by the NPY genotype. The NPY SNP (rs16147) had previously been related to levels of well-being, notably anxiety and depression (Zhou et al., 2008; Sommer et al., 2010; Zhang et al., 2012). It was determined in the present investigation that the NPY SNP did not specifically alter the risk of anxiety or depression being present, but was accompanied by improved psychological well-being, which seemed to be related to greater social connectedness. It similarly appeared that with higher levels of early life emotional trauma, levels of social connectedness were lower as was overall well-being. The NPY SNP, however, was accompanied by an increase in the buffering capacity associated with 
social connectedness. Although social connectedness was accompanied by enhanced psychological well-being irrespective of genotypes, the link was greater among individuals with the GG genotype.

Individuals that possess the non-protective $\mathrm{G}$ allele, may be more receptive to learning resilient behaviors or more impacted by intervention. In this regard, mild trauma during the course of development may be effective in promoting resilience in the face of a stressor (Heilig et al., 2004; Domschke et al., 2010; Sommer et al., 2010). Thus, while it may be true that the A allele is protective by buffering the effects of trauma, individuals with the $\mathrm{G}$ mutation, when in a supportive and social environmental do, in fact, become more resilience to adversity and have higher levels of psychological well-being.

It is difficult to define the physiological and behavioral consequences of of the NPY polymorphism given the discrepancies in the literature concerning which allele actually is accompanied by an increase of NPY production. The A allele is usually seen as being protective against pathology, but it is uncertain whether this is related to an increase of NPY s opposed to down-stream changes that could occur. The way in which NPY functions in stress modulation, is believed to be through an interaction with corticotropin releasing hormone, thus reducing anxiety (Witt el al., 2011; Wu et al., 2011). However, contradictory data suggest that the G allele actually results in increased NPY release, compared to that associated with the A allele (Sommer et al., 2010; Buckland et al., 2005; Itokawa et al., 2003). Several studies have indicated that the environment under which samples were taken altered the levels of NPY differently among genotypes. In a stressful situation, G carriers exhibited higher levels of plasma NPY, whereas A carriers exhibited higher levels at rest (Zhou et al., 2008; Shah et al., 2009). This could support the idea that individuals that possess the GG genotype will have higher levels of NPY in times of 
stress, allowing them to better manage stressful situations and are more susceptible to resilient behaviors. At the same time, such findings suggest that the relationship between NPY and behavioral outcomes can be complex, and could potentially vary yet again in other contexts.

\section{Moderating Effects of Condition}

An additional aspect of the present study concerned the effect that being a highperforming athlete may have on psychological well-being. While not significant, it appeared that university varsity athletes exhibited slightly elevated levels of psychological well-being compared to a control population. There are many aspects to high level sport that may lead an individual to have higher levels of resilience or psychological well-being. Conversely, it may be that becoming an elite athlete requires an individual to already be resilient to stressors. Some of these resilience factors might include determination, self-belief and mental toughness (Wiser \& Thiel, 2014). In addition, the team aspect of athletics may provide increased social connectedness. Thus, athletic involvement was investigated as a potential buffer to the negative impact that early life trauma has on both well-being and social connectedness. Trauma has been shown to decrease levels of social connectedness, possibly due to difficulties forming personal relationships or an individuals' lack of feeling of belonging (Lee \& Robbins, 1995).

Varsity athletics gives students a sense of belonging that may not be felt by other students that are not involved in university athletic programs. In line with this, being a university athlete buffered against emotional trauma to increase levels of social connectedness compared to those within the control group. There were a number of students within the control group that selfidentified as athletes, however, when these individuals were pooled with the varsity athletes, the 
links between early life trauma and social connectedness were no longer significant. Due to this, it appears simply being part of a team, or identifying as an athlete benefits psychological wellbeing and buffers against decreases in social connectedness following trauma.

\section{Genotype and Condition Interaction}

It was hypothesized that athletes and controls would differ in levels of stress resilience. In general, there were no significant differences in levels of psychological well-being between athletes and non-athletes. It was found, however, that consistent with previous findings the nonathletes exhibited higher levels of psychological well-being, but only if they had the AA genotype. Curiously, however, among the athletes the greatest psychological resilience was apparent among the GG carriers. This finding was reminiscent of the relationship between social connectedness and well-being, where those with the GG genotype appeared to be more susceptible to the psychological benefits of social connectedness. As previously discussed, university athletics largely incorporates feelings of belonging and connectedness, whereas the control group may lack a social identity within their university. It could be that other characteristics (e.g., determination and positive cognition) that are found primarily in high performing athletes, as well as other resilient groups, likewise vary with the GG genotype to a larger degree than those that carry the A allele.

\section{$\underline{\text { Limitations and Conclusions }}$}

There are several limitations associated with the current findings. The sample size was modest, especially when considering individuals divided into groups based on their genotype. It is also difficult to know whether levels of psychological well-being and resilience in a university 
population is relevant to other populations that experienced emotional trauma. In addition, it is uncertain whether differences in well-being would occur among various levels of elite athletes, which were not represented in the present sample.

Due to the nature of the research, all psychosocial variables were determined based on self-reported data, which can potentially be non-reliable, varying with the individual's current mood state. Furthermore, owing to differences in the time of year during which data were collected, responses of participants might have varied with the stresses associated with academic and athletic pressures (e.g., time commitments). In addition, seasonal variations in mood collected throughout the calendar year may alter participant's responses.

As previously mentioned, it is difficult to know the physiological and behavioral effects of NPY polymorphisms. Environment has been documented to differentially influence each allele; under stressor conditions, those carrying the G allele have increased production of NPY, whereas at rest the A allele results in increased NPY expression (Zhou et al., 2008). Furthermore, in addition to levels of NPY, it is essential to assess NPY receptors as these may be key to the development of pathology following stress. Animal studies that examined Y1 and Y2-type receptors in relation to social interaction as well as anxiety-like symptoms, indicated that antagonizing the Y1-type receptor in various brain regions of rodents resulted in anxiogenic effects (Wahlestedt, et al., 1986; Heilig et al., 1993; Heilig, 1995), whereas knocking out the Y2type receptor provoked an anxiolytic effect (Tschenett et al., 2003).

Early life trauma has been linked to decreased psychological well-being (Campbell-Sills, Cohan and Stein, 2006; Collishaw et al., 2007), although marked individual differences exist in this respect, possibly being related to social connectedness. In general, social connectedness has been positively linked to increased psychological well-being and resilience, but trauma 
experiences may undermine an individual's sense of belonging and social connectedness. Additionally, genetic factors influence individuals' reactions to stressors, which may influence their susceptibility to illness later in life. Specifically, neuropeptide Y has been linked to the stress response and differences in anxiety and depression that may evolve following trauma. The current findings indicated that the link between social connectedness and psychological wellbeing was moderated by an NPY polymorphisms. In addition, the relationship between early life trauma and social connectedness varied as a function of whether individuals were varsity athletes or not. Among the athletes, trauma experiences were unrelated to social connectedness, whereas a significant decrease in the feelings of social connectedness was apparent among the nonathletes. Likewise, genotype and athletic condition interacted in predicting psychological wellbeing in that the normally protective genotype did not function in this capacity amongst the high performing athletes. It is presently unclear why this should have been the case, but assuming the findings were reliable, these data suggest that a straightforward relationship between the NPY genotype and resilience is overly simplistic, and probably involves the contribution of multiple factors. 


\section{References}

Affleck, G., \& Tennen, H. (1996). Construing benefits from adversity: adaptational significance and dispositional underpinnings. Journal of Personality, 64(4), 899-922.

http://doi.org/10.1111/j.1467-6494.1996.tb00948.x

Alim, T. N., Feder, A., Graves, R. E., Wang, Y., Weaver, J., Westphal, M., ... Charney, D. S. (2008). Trauma, resilience, and recovery in a high-risk African-American population. American Journal of Psychiatry, 165(12), 1566-1575. http://doi.org/10.1176/appi.ajp.2008.07121939

Amstadter, A. B., Koenen, K. C., Ruggiero, K. J., Acierno, R., Kilpatrick, D. G., \& Gelernter, J. (2011). NIH Public Access, 27(3), 270-275. http://doi.org/10.1002/da.20648.NPY

Banyard, V. L., \& Williams, L. M. (2007). Women's voices on recovery: A multi-method study of the complexity of recovery from child sexual abuse. Child Abuse and Neglect, 31(3), 275-290. http://doi.org/10.1016/j.chiabu.2006.02.016

Beck, A.T., Ward, C.H., Mendelson, M., Mock, J., \& Erbaugh, J. (1961). An inventory of measuring depression. Archives of General Psychiatry, 4, 561-571.

Bjørnebekk, A., Mathé, A. a, \& Brené, S. (2005). The antidepressant effect of running is associated with increased hippocampal cell proliferation. The International Journal of Neuropsychopharmacology, 8(3), 357-368. http://doi.org/10.1017/S1461145705005122

Bleuler, M. (1984). Different forms of childhood stress and patterns of adult psychiatric outcome. Children at risk for schizophrenia, 537-542.

Bonanno, G. a, Galea, S., Bucciarelli, A., \& Vlahov, D. (2007). What predicts psychological resilience after disaster? The role of demographics, resources, and life stress. Journal of Consulting and Clinical Psychology, 75(5), 671-682. http://doi.org/10.1037/0022006X.75.5.671

Broekman, B. F. P., Olff, M., \& Boer, F. (2007). The genetic background to PTSD. Neuroscience and Biobehavioral Reviews, 31(3), 348-362. http://doi.org/10.1016/j.neubiorev.2006.10.001

Buckland, P. R., Hoogendoorn, B., Coleman, S. L., Guy, C. A., Smith, S. K., \& O’Donovan, M. C. (2005). Strong bias in the location of functional promoter polymorphisms. Human Mutation, 26(3), 214-223. http://doi.org/10.1002/humu.20207

Campbell-Sills, L., Cohan, S. L., \& Stein, M. B. (2006). Relationship of resilience to personality, coping, and psychiatric symptoms in young adults. Behaviour Research and Therapy, 44(4), 585-599. http://doi.org/10.1016/j.brat.2005.05.001 
Carver, C. S., Scheier, M. F., \& Segerstrom, S. C. (2010). Optimism. Clinical Psychology Review, 30(7), 879-889. http://doi.org/10.1016/j.cpr.2010.01.006

Carver, C. S., \& Segerstrom, S. C. (2014). NIH Public Access, 30(7), 879-889. http://doi.org/10.1016/j.cpr.2010.01.006.Optimism

Charney, D. S. (2004). Psychobiological Mechanisms of Resilience and Vulnerability. FOCUS, 2(3), 368-391. http://doi.org/10.1176/foc.2.3.368

Charney, D., \& Southwick, S. (2007). Social Support and Resilience To Stress :, 35-40.

Clarke, P.J., Marshall, V.W., Ryff, C.D., \& Wheaton, B. (2001). Measuring Psychological WellBeing in the Canadian Study of Health and Aging. International Psychogeriatrics, 13, 7990.

Clauss-Ehlers, C. S. (2008). Sociocultural factors, resilience, and coping: Support for a culturally sensitive measure of resilience. Journal of Applied Developmental Psychology, 29(3), 197212. http://doi.org/10.1016/j.appdev.2008.02.004

Cohen, H., Liu, T., Kozlovsky, N., Kaplan, Z., Zohar, J., \& Mathé, A. a. (2012). The Neuropeptide Y (NPY)-ergic System is Associated with Behavioral Resilience to Stress Exposure in an Animal Model of Post-Traumatic Stress Disorder. Neuropsychopharmacology, 37(2), 350-363. http://doi.org/10.1038/npp.2011.230

Collishaw, S., Pickles, A., Messer, J., Rutter, M., Shearer, C., \& Maughan, B. (2007). Resilience to adult psychopathology following childhood maltreatment: Evidence from a community sample. Child Abuse \& Neglect, 31(3), 211-229. http://doi.org/10.1016/j.chiabu.2007.02.004

Cruwys, T., Dingle, G. A., Haslam, C., Haslam, S. A., Jetten, J., \& Morton, T. A. (2013). Social group memberships protect against future depression, alleviate depression symptoms and prevent depression relapse. Social Science and Medicine, 98, 179-186. http://doi.org/10.1016/j.socscimed.2013.09.013

Dannlowski, U., Stuhrmann, A., Beutelmann, V., Zwanzger, P., Lenzen, T., Grotegerd, D., ... Kugel, H. (2012). Limbic scars: Long-term consequences of childhood maltreatment revealed by functional and structural magnetic resonance imaging. Biological Psychiatry, 71(4), 286-293. http://doi.org/10.1016/j.biopsych.2011.10.021

Davey, M., Eaker, D. G., \& Walters, L. H. (2003). Resilience Processes in Adolescents: Personality Profiles, Self-Worth, and Coping. Journal of Adolescent Research, 18(4), 347362. http://doi.org/10.1177/0743558403018004002

Davydov, D. M., Stewart, R., Ritchie, K., \& Chaudieu, I. (2010). Resilience and mental health. Clinical Psychology Review, 30(5), 479-495. http://doi.org/10.1016/j.cpr.2010.03.003 
Deci, E. L., \& Ryan, R. M. (2008). Facilitating optimal motivation and psychological well-being across life's domains. Canadian Psychology/Psychologie canadienne, 49(1), 14.

Dignam, P. (2009). Treatment-resistant depression... Aust N Z J Psychiatry 2008;42:751-762. Australian \& New Zealand Journal of Psychiatry, 43(1), 87. Retrieved from http://proxy.lib.sfu.ca

Domschke, K., Dannlowski, U., Hohoff, C., Ohrmann, P., Bauer, J., Kugel, H., ... Baune, B. T. (2010). Neuropeptide Y (NPY) gene: Impact on emotional processing and treatment response in anxious depression. European Neuropsychopharmacology, 20(5), 301-309. http://doi.org/10.1016/j.euroneuro.2009.09.006

Donner, J., Sipilä, T., Ripatti, S., Kananen, L., Chen, X., Kendler, K. S., ... Hovatta, I. (2012). Support for involvement of glutamate decarboxylase 1 and neuropeptide y in anxiety susceptibility. American Journal of Medical Genetics, Part B: Neuropsychiatric Genetics, 159 B(3), 316-327. http://doi.org/10.1002/ajmg.b.32029

Dumont, M., \& Provost, M. A. (1999). Resilience in adolescents: Protective role of social support, coping strategies, self-esteem, and social activities on experiences of stress and depression. Journal of youth and adolescence. 28, 3.

Dumont, Y., Jacques, D., Bouchard, P., \& Quirion, R. (1998). Species differences in the expression and distribution of the neuropeptide Y Y1, Y2, Y4, and Y5 receptors in rodents, guinea pig, and primates brains. Journal of Comparative Neurology, 402(3), 372-384. http://doi.org/10.1002/(SICI)1096-9861(19981221)402:3<372::AID-CNE6>3.0.CO;2-2

Edward, K. (2005a). Resilience: When Coping Is Emotionally Intelligent. Journal of the American Psychiatric Nurses Association, 11(2), 101-102.

http://doi.org/10.1177/1078390305277526

Edward, K. -1. (2005b). Resilience: When Coping Is Emotionally Intelligent. Journal of the American Psychiatric Nurses Association, 11(2), 101-102.

http://doi.org/10.1177/1078390305277526

Enman, N. M., Sabban, E. L., McGonigle, P., \& Van Bockstaele, E. J. (2015). Targeting the neuropeptide Y system in stress-related psychiatric disorders. Neurobiology of Stress, 1, 3343. http://doi.org/10.1016/j.ynstr.2014.09.007

Feder, A., Nestler, E. J., \& Charney, D. S. (2009). Psychobiology and molecular genetics of resilience. Nature Reviews. Neuroscience, 10(6), 446-57. http://doi.org/10.1038/nrn2649

Friborg, O., Hjemdal, O., Rosenvinge, J. H., Martinussen, M., Aslaksen, P. M., \& Flaten, M. A. (2006). Resilience as a moderator of pain and stress. Journal of Psychosomatic Research, 61(2), 213-219. http://doi.org/10.1016/j.jpsychores.2005.12.007 
Folkman, S., \& Moskowitz, J. T. (2000). Positive affect and the other side of coping. American Psychologist, 55(6), 647-654. doi:http://dx.doi.org.proxy.library.carleton.ca/10.1037/0003066X.55.6.647

Fontana, A. F., Kerns, R. D., Rosenberg, R. L., \& Colonese, K. L. (1989). Support, stress, and recovery from coronary heart disease: A longitudinal causal model. Health Psychology. US: Lawrence Erlbaum Associates. http://doi.org/10.1037/0278-6133.8.2.175

Haddadi, P., \& Besharat, M. A. (2010). Resilience, vulnerability and mental health. Procedia Social and Behavioral Sciences, 5(2), 639-642. http://doi.org/10.1016/j.sbspro.2010.07.157

Harris, A. H. S., Cronkite, R., \& Moos, R. (2006). Physical activity, exercise coping, and depression in a 10-year cohort study of depressed patients. Journal of Affective Disorders, 93(1-3), 79-85. http://doi.org/10.1016/j.jad.2006.02.013

Heilig, M. (1995). Antisense inhibition of neuropeptide Y (NPY)-Y1 receptor expression blocks the anxiolytic-like action of NPY in amygdala and paradoxically increases feeding. Regulatory Peptides, $<\mathrm{i}$

Heilig, M. (2004). The NPY system in stress, anxiety and depression. Neuropeptides, 38(4), 213-224. http://doi.org/10.1016/j.npep.2004.05.002

Heilig, M., Zachrisson, O., Thorsell, A., Ehnvall, A., Ekman, R., Mottagui-tabar, S., ... Marie, A. (2004). Decreased cerebrospinal fluid neuropeptide Y ( NPY ) in patients with treatment refractory unipolar major depression : preliminary evidence for association with preproNPY gene polymorphism. Journal of Psychiatric Research, 38, 113-121. http://doi.org/10.1016/S0022-3956(03)00101-8

Herman-Stahl, M., \& Petersen, A. C. (1996). The protective role of coping and social resources for depressive symptoms among young adolescents. Journal of Youth and Adolescence, 25(6), 733-753. http://doi.org/10.1007/BF01537451

Hohmann, S., Buchmann, A. F., Witt, S. H., Rietschel, M., Jennen-Steinmetz, C., Schmidt, M. H., ... Laucht, M. (2012). Increasing association between a neuropeptide Y promoter polymorphism and body mass index during the course of development. Pediatric Obesity, 7(6), 453-460. http://doi.org/10.1111/j.2047-6310.2012.00069.x

Holland, a., \& Andre, T. (1987). Participation in Extracurricular Activities in Secondary School: What Is Known, What Needs to Be Known? Review of Educational Research, 57(4), 437466. http://doi.org/10.3102/00346543057004437

Itokawa, M., Arai, M., Kato, S., Ogata, Y., Furukawa, A., Haga, S., ... Yoshikawa, T. (2003). Association between a novel polymorphism in the promoter region of the neuropeptide $\mathrm{Y}$ gene and schizophrenia in humans. Neuroscience Letters, 347(3), 202-204. http://doi.org/10.1016/S0304-3940(03)00718-3 
Janssen, J., Hulshoff Pol, H. E., de Leeuw, F.-E., Schnack, H. G., Lampe, I. K., Kok, R. M., ... Heeren, T. J. (2007). Hippocampal volume and subcortical white matter lesions in late life depression: comparison of early and late onset depression. Journal of Neurology, Neurosurgery, and Psychiatry, 78(6), 638-640. http://doi.org/10.1136/jnnp.2006.098087

Lee, R. M., \& Robbins, S. B. (1998). The relationship between social connectedness and anxiety, self-esteem, and social identity. Journal of Counseling Psychology, 45(3), 338-345. http://doi.org/10.1037/0022-0167.45.3.338

Lee, R. M., \& Robbines, S. B. (1995). Measuring belongingness: The Social Connectedness and the Social Assurance scales. Journal of Counseling Psychology, (232-241). Retrieved from http://search.p

Leontopoulou, S. (2010). An Exploratory Study of Altruism in Greek Children: Relations with Empathy, Resilience and Classroom Climate. Psychology, 01(05), 377-385. http://doi.org/10.4236/psych.2010.15047

Leipold, B., \& Greve, W. (2009). Resilience. European Psychologist, 14(1), 40-50. http://doi.org/10.1027/1016-9040.14.1.40

Manuscript, A. (2013). Neurobiology of Resilience, 15(11), 1475-1484. http://doi.org/10.1038/nn.3234.Neurobiology

McEwen, B. S. (2003). Mood disorders and allostatic load. Biological Psychiatry, 54(3), 200207. http://doi.org/10.1016/S0006-3223(03)00177-X

McEwen, B. S. (2000). Allostasis and allostatic load: Implications for neuropsychopharmacology. Neuropsychopharmacology, 22(2), 108-124. http://doi.org/10.1016/S0893-133X(99)00129-3

McGuire, J. L., Larke, L. E., Sallee, F. R., Herman, J. P., \& Sah, R. (2011). Differential Regulation of Neuropeptide $\mathrm{Y}$ in the Amygdala and Prefrontal Cortex during Recovery from Chronic Variable Stress. Frontiers in Behavioral Neuroscience, 5(September), 1-6. http://doi.org/10.3389/fnbeh.2011.00054

Mealer, M., Jones, J., \& Moss, M. (2012). A qualitative study of resilience and posttraumatic stress disorder in United States ICU nurses. Intensive Care Medicine, 38, 1445-1451. http://doi.org/10.1007/s00134-012-2600-6

Melas, P. a, Lennartsson, a, Vakifahmetoglu-Norberg, H., Wei, Y., Åberg, E., Werme, M., ... Lavebratt, C. (2013). Allele-specific programming of Npy and epigenetic effects of physical activity in a genetic model of depression. Translational Psychiatry, 3(October 2012), e255. http://doi.org/10.1038/tp.2013.31

Mickey, B. J., Zhou, Z., Heitzeg, M. M., Heinz, E., Hodgkinson, C. a, Hsu, D. T., ... Zubieta, J.K. (2011). Emotion processing, major depression, and functional genetic variation of 
neuropeptide Y. Archives of General Psychiatry, 68(2), 158-166.

http://doi.org/10.1001/archgenpsychiatry.2010.197

Morales-Medina, J. C., Dumont, Y., \& Quirion, R. (2010a). A possible role of neuropeptide Y in depression and stress. Brain Research, 1314, 194-205.

http://doi.org/10.1016/j.brainres.2009.09.077

Morales-Medina, J. C., Dumont, Y., \& Quirion, R. (2010b). A possible role of neuropeptide Y in depression and stress. Brain Research, 1314, 194-205.

http://doi.org/10.1016/j.brainres.2009.09.077

Morgan, C. A., Rasmusson, A. M., Wang, S., Hoyt, G., Hauger, R. L., \& Hazlett, G. (2002). Neuropeptide-Y, cortisol, and subjective distress in humans exposed to acute stress: Replication and extension of previous report. Biological Psychiatry, 52(2), 136-142. http://doi.org/10.1016/S0006-3223(02)01319-7

Paykel, E. S. (1994). Life events, Social support and depression. Acta Psychiatrica Scandinavica, 89, 50-58. http://doi.org/10.1111/j.1600-0447.1994.tb05803.x

Preacher, K. J., Curran, P. J., \& Bauer, D. J. (2006). Computational tools for probing interactions in multiple linear regression, multilevel modeling, and latent curve analysis. Journal of educational and behavioral statistics, 31(4), 437-448.

Pruessner, J. C., Baldwin, M. W., Dedovic, K., Renwick, R., Mahani, N. K., Lord, C., ... Lupien, S. (2005). Self-esteem, locus of control, hippocampal volume, and cortisol regulation in young and old adulthood. NeuroImage, 28(4), 815-826.

http://doi.org/10.1016/j.neuroimage.2005.06.014

Rozanski, A., Blumenthal, J. A., \& Kaplan, J. (1999). Impact of Psychological Factors on the Pathogenesis of Cardiovascular Disease and Implications for Therapy. Circulation, 99(16), 2192-2217. http://doi.org/10.1161/01.CIR.99.16.2192

Russo, S. J., Murrough, J. W., Han, M.-H., Charney, D. S., \& Nestler, E. J. (2012). Neurobiology of resilience. Nat Neurosci, 15(11), 1475-1484. Retrieved from http://dx.doi.org/10.1038/nn.3234

Rutten, B. P. F., Hammels, C., Geschwind, N., Menne-Lothmann, C., Pishva, E., Schruers, K., ... Wichers, M. (2013). Resilience in mental health: linking psychological and neurobiological perspectives. Acta Psychiatrica Scandinavica, 128(1), 3-20. http://doi.org/10.1111/acps.12095

Rutter, M. (2007). Resilience, competence, and coping. Child Abuse \& Neglect, 31(3), 205-209. http://doi.org/10.1016/j.chiabu.2007.02.001

Ryff, C. D. (1989). Happiness is everything, or is it? Explorations on the meaning of psychological well-being. Journal of personality and social psychology, 57(6), 1069. 
Ryff, C. D., \& Keyes, C. L. M. (1995). The structure of psychological well-being revisited. Journal of personality and social psychology, 69(4), 719.

Sagone, E., \& De Caroli, M. E. (2014). Relationships between psychological well-being and resilience in middle and late adolescents. Procedia-Social and Behavioral Sciences, 141, 881-887.

Sah, R., Ekhator, N. N., Jefferson-Wilson, L., Horn, P. S., \& Geracioti, T. D. (2014).

Cerebrospinal fluid neuropeptide $\mathrm{Y}$ in combat veterans with and without posttraumatic stress disorder. Psychoneuroendocrinology, 40, 277-283.

http://doi.org/10.1016/j.psyneuen.2013.10.017

Sah, R., \& Geracioti, T. D. (2013). Neuropeptide Y and posttraumatic stress disorder. Molecular Psychiatry, 18(6), 646-655. http://doi.org/10.1038/mp.2012.101

Sajdyk, T. J., Johnson, P. L., Leitermann, R. J., Fitz, S. D., Dietrich, A., Morin, M., ... Shekhar, A. (2008). Neuropeptide $Y$ in the amygdala induces long-term resilience to stress- induced reductions in social responses but not hypothalamic-adrenal- pituitary axis activity or hyperthermia. J Neurosci, 28(4), 893-903. http://doi.org/10.1523/JNEUROSCI.065907.2008

Sambasivarao, S. V. (2013). NIH Public Access, 18(9), 1199-1216. http://doi.org/10.1016/j.micinf.2011.07.011.Innate

Schaal, K., Tafflet, M., Nassif, H., Thibault, V., Pichard, C., Alcotte, M., ... Toussaint, J.-F. (2011). Psychological balance in high level athletes: gender-based differences and sportspecific patterns. PloS One, 6(5), e19007. http://doi.org/10.1371/journal.pone.0019007

Serova, L. I., Laukova, M., Alaluf, L. G., Pucillo, L., \& Sabban, E. L. (2014). Intranasal neuropeptide $\mathrm{Y}$ reverses anxiety and depressive-like behavior impaired by single prolonged stress PTSD model. European Neuropsychopharmacology, 24(1), 142-147. http://doi.org/10.1016/j.euroneuro.2013.11.007

Serova, L. I., Tillinger, A., Alaluf, L. G., Laukova, M., Keegan, K., \& Sabban, E. L. (2013). Single intranasal neuropeptide $\mathrm{Y}$ infusion attenuates development of PTSD-like symptoms to traumatic stress in rats. Neuroscience, 236, 298-312.

http://doi.org/10.1016/j.neuroscience.2013.01.040

Shi, M., Liu, L., Wang, Z. Y., \& Wang, L. (2015). The Mediating Role of Resilience in the Relationship between Big Five Personality and Anxiety among Chinese Medical Students: A Cross-Sectional Study. Plos One, 10(3), e0119916. http://doi.org/10.1371/journal.pone.0119916

Simeon, D., Yehuda, R., Cunill, R., Knutelska, M., Putnam, F. W., \& Smith, L. M. (2007). Factors associated with resilience in healthy adults. Psychoneuroendocrinology, 32(8-10), 1149-1152. http://doi.org/10.1016/j.psyneuen.2007.08.005 
Sommer, W. H., Lidström, J., Sun, H., Passer, D., Eskay, R., Parker, S. C. J., ... Heilig, M. (2010). Human NPY promoter variation rs 16147:T $>C$ as a moderator of prefrontal NPY gene expression and negative affect. Human Mutation, 31(8), E1594-608. http://doi.org/10.1002/humu.21299

Sommer, W. H., Lidström, J., Sun, H., Passer, D., Eskay, R., Parker, S. C. J., ... Laucht, M. (2011). NIH Public Access, 31(8), 1-16. http://doi.org/10.1002/humu.21299.Human

Souri, H., \& Hasanirad, T. (2011). Relationship between resilience, optimism and psychological well-being in students of medicine. Procedia-Social and Behavioral Sciences, 30, 15411544 .

Southwick, S., Bonanno, G., Masten, A., Panter-Brick, C., \& Yehuda, R. (2011). Interdisciplinary Perspectives. European Journal of Psychotraumatology, 1(2), 1-14. http://doi.org/10.3402/ejpt.v5.25338

Southwick, S. M., Vythilingam, M., \& Charney, D. S. (2005). The Psychobiology of Depression and Resilience to Stress: Implications for Prevention and Treatment*. Annual Review of Clinical Psychology, 1(1), 255-291. http://doi.org/10.1146/annurev.clinpsy.1.102803.143948

Steinhardt, M., \& Dolbier, C. (n.d.). Evaluation of a resilience intervention to enhance coping strategies and protective factors and decrease symptomatology. Journal of American College Health : J of ACH, 56(4), 445-453. http://doi.org/10.3200/JACH.56.44.445-454

Tschenett, A., Singewald, N., Carli, M., Balducci, C., Salchner, P., Vezzani, A., ... Sperk, G. (2003). Reduced anxiety and improved stress coping ability in mice lacking NPY-Y2 receptors. European Journal of Neuroscience, 18(1), 143-148. http://doi.org/10.1046/j.1460-9568.2003.02725.x

Vaillant, G. E. (1992). The historical origins and future potential of Sigmund Freud's concept of the mechanisms of defence. International review of psycho-analysis.

Warner, L. M., Schwarzer, R., Sch??z, B., Wurm, S., \& Tesch-R??mer, C. (2012). Healthspecific optimism mediates between objective and perceived physical functioning in older adults. Journal of Behavioral Medicine, 35(4), 400-406. http://doi.org/10.1007/s10865-0119368-y

Widdowson, P. S., Ordway, G. A., \& Halaris, A. E. (1992). Reduced Neuropeptide Y Concentrations in Suicide Brain. Journal of Neurochemistry, 59(1), 73-80. http://doi.org/10.1111/j.1471-4159.1992.tb08877.x

Widom, C. S., DuMont, K., \& Czaja, S. J. (2007). A prospective investigation of major depressive disorder and comorbidity in abused and neglected children grown up. Archives of General Psychiatry, 64(1), 49-56. http://doi.org/10.1001/archpsyc.64.1.49 
Wieser, R., \& Thiel, H. (2014). A survey of "mental hardiness" and "mental toughness" in professional male football players. Chiropr Man Therap, 22(1), 17.

http://doi.org/10.1186/2045-709X-22-17

Witt, S. H., Buchmann, A. F., Blomeyer, D., Nieratschker, V., Treutlein, J., Esser, G., ... Zimmermann, U. S. (2011). An interaction between a neuropeptide Y gene polymorphism and early adversity modulates endocrine stress responses. Psychoneuroendocrinology, 36(7), 1010-1020. http://doi.org/10.1016/j.psyneuen.2010.12.015

Wu, G., Feder, A., Cohen, H., Kim, J. J., Calderon, S., Charney, D. S., \& Mathé, A. a. (2013). Understanding resilience. Frontiers in Behavioral Neuroscience, 7(February), 10. http://doi.org/10.3389/fnbeh.2013.00010

Yehuda, R., Brand, S., \& Yang, R. K. (2006). Plasma neuropeptide Y concentrations in combat exposed veterans: Relationship to trauma exposure, recovery from PTSD, and coping. Biological Psychiatry, 59(7), 660-663. http://doi.org/10.1016/j.biopsych.2005.08.027

Zhang, K., Rao, F., Pablo Miramontes-Gonzalez, J., Hightower, C. M., Vaught, B., Chen, Y., ... O'Connor, D. T. (2012). Neuropeptide y (NPY): Genetic variation in the human promoter alters glucocorticoid signaling, yielding increased NPY secretion and stress responses. Journal of the American College of Cardiology, 60(17), 1678-1689. http://doi.org/10.1016/j.jacc.2012.06.042

Zhou, Z., Zhu, G., Hariri, A. R., Enoch, M.-A., Scott, D., Sinha, R., ... Goldman, D. (2008). Genetic variation in human NPY expression affects stress response and emotion. Nature, 452(7190), 997-1001. http://doi.org/10.1038/nature06858

Zhu, D. C., Covassin, T., Nogle, S., Doyle, S., Russell, D., Pearson, R. L., ... Kaufman, D. I. (2014). A Potential Biomarker in Sports-Related Concussion: Brain Functional Connectivity Alteration of the Default-Mode Network Measured with Longitudinal RestingState fMRI Over Thirty Days. Journal of Neurotrauma, 32(5), 327-41. http://doi.org/10.1089/neu.2014.3413 


\title{
Appendices
}

Appendix A: Recruitment Notice

\section{Recruitment Notice}

\section{Study Title:}

\begin{abstract}
The purpose of this study is to determine the characteristics of resilience to stress and whether it is in

partly genetic. As well, it is of interest to determine whether resiliency factors differ between varsity athletes and non-athletes. .
\end{abstract}

Description: The purpose of this study is to examine the factors that aid in your resilience to the negative health effects of stressful events. Additionally, we want to assess whether athletic ability can differentiate between levels of resilience. We are interested in determining the different coping styles that are involved in dealing with stress and whether or not they are tied to resilience. Finally, we would like to know if there is a genetic tie to resilience and if there is a difference between the two groups.

You will be asked to provide one saliva sample, and fill out questionnaires; some of the questions are of a sensitive nature in this study as we will be asking you personal questions which may cause discomfort. The study will take approximately $75 \mathrm{~min}$ to complete.

***Please DO NOT eat, drink (other than water) or smoke 30 minutes prior to the experiment***

This study has received clearance by the Carleton University Psychology Research Ethics Board (Reference \#__ ).

\section{Eligibility: Carleton University Undergraduate Students}

Compensation: $1.50 \%$ towards any eligible SONA course 


\section{Athlete Recruitment Email}

\section{Good afternoon,}

Thank you in advance for taking the time to read this email. I have mentioned previously to you all that I will be conducting a research project to complete my master's degree that requires data from athletes. Many of you may know I am a first year Neuroscience Masters student here and have been a varsity athlete at Carleton for 5 years playing both golf and hockey. My thesis will require a large sample of athletes and this is where I would need your help.

My project is looking at the difference between athlete and normal populations with regards to a certain gene that is thought to play a large role in resilience. What it would require of your athletes is to fill out a questionnaire as well as give a saliva sample. This would take about an hour. The study can take place at any time at your convenience, as to have no impact on practice or game time.

The reason I am emailing you is because I would greatly appreciate your help through support so that I will be able to get enough participants (about 200 athletes). I am open to a lot of ways of getting athlete participation. Also, athletes that are enrolled in first or second year psychology classes can obtain 1.5 SONA credits and those that are not can receive a $5 \$$ Tim Horton's gift card.

Thank you again for your time in reading this email, I would greatly appreciate some feedback on your thoughts if you are on board with participation.

Cheers and Go Ravens!,

Samantha Coates 


\section{$\underline{\text { Appendix B: Informed Consent }}$}

\section{Informed Consent}

The purpose of an informed consent is to ensure that you understand the purpose of the study and the nature of your involvement. The informed consent has to provide sufficient information such that you have the opportunity to determine whether you wish to participate in the study.

\section{Study title: Genetic Basis of Resilience of Stress: A Comparison between Varsity Athletes and Non-Athletes}

\section{Contacts}

The following people are involved in this research project and may be contacted at any time if you have further questions about this project, what it means, or concerns about how it was conducted:

Samantha Coates, Graduate Researcher, Department of Neuroscience samantha.coates@,carleton.ca

Dr. Hymie Anisman, Faculty Member, Department of Neuroscience

Phone: 613 520-3570, hymie_anisman@,carleton.ca

Dr. Kim Matheson, Faculty Member, Department of Psychology

Phone: 613 520-2699, kim.matheson@carleton.ca

Should you have any ethical concerns about this research, please contact Dr. Shelley Brown at: shelley.brown@carleton.ca (613-520-2600 ext. 1505). For any other concerns, please contact Dr. Joanne Pozzulo (Chair, Department of Psychology, 613-520-2600, ext. 1412, psychchair@carleton.ca) or Dr. John Stead (Chair, Department of Neuroscience, 613-520-2600 ext.8774,john.stead@carleton.ca)

Purpose: The purpose is to find which factors lead to a resilient person. Specifically we will be looking at how individuals cope with stressful events as well as mood. Further we are interested in determining whether certain genes (NPY) also play a role in resilience. Additionally, we are 
interested in determining whether athletes and non-athletes differ in stressful events and resilience levels. Further, we are interested in looking at how genes can affect these abilities. Additionally, we would like to determine whether there is a connection between coping abilities, techniques and genetics on whether an individual is a successful athlete. This research will help to identify differences in the population that can attribute to differences in athletic and mental coping ability.

\section{What are we asking you to do?}

We will be asking you to fill out a number of questionnaires regarding information related to your background (e.g., demographic, family, city of residence), medical history (e.g., current medications and history of illnesses and psychological disorders), stress management (e.g., coping styles), mood (e.g., feelings of depression and anxiety), sense of well-being, and your perceived ability to deal with both stressful events and everyday life.

We are also asking participants to provide a DNA sample through the simple act of spitting into a tube however, due to the relatively large volume of saliva required $(\sim 1 \mathrm{ml})$ this can take up to 5 minutes.

This study should take approximately 60 minutes to complete.

\section{What will I receive for my participation?}

You will be assigned $2.00 \%$ course credit.

\section{Potential risks or causes of discomfort for participants}

There are no physical risks in this study. There may be some discomfort or anxiety experienced when responding to some questions of a sensitive nature in this study. We will be asking you to fill out questionnaires related to stress management, interpersonal relationships with family and friends, and feelings of well-being. If this is the case, the Debriefing form at the end of the study contains contact information for people who are available to help. You can also choose to withdraw from the study at any point. We are looking to collect a saliva sample, which may take up to 5 minutes. Some participants may therefore feel discomfort or embarrassment about spitting into a tube in the presence of the researcher and other students, in which case you may feel free to leave the room and finish the sample. You will be asked to not drink, eat, smoke or chew gum for 30 minutes before providing this sample.

\section{Anonymity and confidentiality}

All information and samples collected from you for this study will be identified with a code number, as opposed to any personal identifiers such as your name or address. We will maintain a separate record that matches your personal identification details with this code number. This is necessary in order for us to re-contact you in the future (with your express permission to do so), and so that we can respect your right to withdraw from the study at a later date (to be described 
below). However, this record that allows your identity to be linked to your information will kept in a separate and secured location, and will only be accessible to the researchers, in order to maintain anonymity and confidentiality of your information. All personal identifying information will be destroyed within 3 years of collection. All information is stored on a server only accessible by this research lab.

\section{Genetic testing: Common questions and concerns What is DNA?}

DNA is a large molecule that contains information necessary for our bodies to build all the components needed for our development, growth and survival. This information is commonly referred to as the genetic code or the DNA sequence. Some rare diseases can be attributed entirely to simple errors in our DNA sequence. However, the majority of common diseases (including depression) are caused by a combination of many different genetic factors, together with environmental factors (how we grew up, life events, etc).

\section{What will my DNA be used for?}

If you compare any two people, their DNA will be about $99 \%$ identical. We are interested in the $1 \%$ of DNA that is different between people. Our current plan is to investigate these differences, focusing on just a small proportion of your genes (we are targeting less than 100 of the $\sim 30,000$ genes that humans have), which we anticipate may be involved in risk of either anxiety or depression.

We are also planning future follow-up studies on your DNA, which will extend the analysis to substantially more genes - potentially all genes. Based on the results of the current study, there could be future interactions that may be of interest to study further including but not limited to: relationships between serotonin and depression as well as between neuropeptide $\mathrm{Y}$ and resilience, interactions between oxytocin and dopamine as well as other related genes which could be significant to positive outcomes related to social factors. These future studies will be limited to analyses of the DNA molecule and the genetic code, and will not involve any other use or manipulation of your DNA sample. At the end of this form, you have the option to opt-out of any such future uses of your DNA sample.

\section{How long will my DNA be stored, and potentially used in research?}

By providing a DNA sample and signing this form, you are indicating that you are willing for us to preserve and analyze your DNA sample for an extended period of time (3 years or less). During this period, use of the sample is guaranteed to be limited to studies that read the DNA molecule. Your saliva and any DNA samples will be destroyed, by incineration, no later than 3 years after saliva was collected.

Will I be told the results of my own genetic analysis?

No. Your DNA sample and genetic information will be identified by a code number, and not your name. This preserves confidentiality of this information. Returning your personal genetic 
information to you would require that confidentiality be compromised, so will be avoided. Furthermore, genetic data collected in this study will not allow accurate prediction of whether or not you will develop any disease. Although in the future we hope to be able to use genetic materials to examine disease susceptibility, our research is in a preliminary phase and we are not currently able to provide this kind of information on an individual basis.

Can my DNA ever be used to identify me?

This is a complicated question to answer. Unless you have an identical twin (whose DNA will be identical to yours), your DNA is absolutely unique to you. It is this unique nature of genetic material that allows individuals to be identified based entirely on their DNA, through techniques such as DNA fingerprinting. It is therefore theoretically possible that in the future, your identity could be determined from simply analyzing your DNA sample.

It is extremely unlikely, however, that you could be identified based on your DNA sample. In order to identify you based purely on your DNA sample, it would be necessary to compare your DNA sample that you provide today, with another DNA sample from you in a DNA database, which is linked to your identity. DNA databases do exist in countries including Canada, Australia, USA and UK, but are limited to samples from criminal offenders. Access to these databases is strictly limited to law enforcement agencies thus cannot be accessed by researchers. Access to DNA samples taken for this study will similarly be limited to the researchers, and will not be provided to any law enforcement agency unless we become legally obliged to do so (to our knowledge, this has never happened to any research group). Furthermore, these government DNA databases typically contain information about only 13 regions of human DNA, none of which are to be analyzed in the present study.

If you have any additional questions or concerns, please ask the researcher today, or contact any of the principal investigators at a later date.

\section{Right to withdraw from this study}

Participation in this study is entirely voluntary. At any point during the study you have the right to not complete certain questions or to withdraw with no penalty whatsoever and compensation will still be granted. Furthermore, if at a later date you wish to withdraw from the study, you can contact the principal investigators and we will destroy all of your records (questionnaire answers, responses from the interview, plus DNA sample) from this study. The only exception is where data has already been published. In this instance, unpublished data plus your DNA sample will be destroyed.

\section{Declaration of consent}

To use your DNA for any future research studies that are aimed at analyzing DNA sequence, please indicate below how you would like your sample to be treated in the future by selecting one of the three options. There are no obligations or penalties for you associated with your selection. 
Option 1: Use of my DNA/saliva sample must be strictly limited to the analysis of $<100$ genes, as described in the current research plan. This can only be done within a 3 year period of my saliva being collected.

Option 2: I grant the researcher permission to re-contact me to seek consent to use my DNA/saliva samples in future research studies.

Email: Phone Number:

Option 3: I grant the researcher permission to use my DNA/saliva samples for any future research studies, limited to analyses of the DNA molecule.

This study has been cleared by the Carleton University Psychology Research Ethics Board (Ethics \#

\section{Signatures}

I have read the above form and understand the conditions of my participation. My participation in this study is voluntary, and I understand that if at any time I wish to leave the experiment, I may do so without having to give an explanation and with no penalty whatsoever. Furthermore, $I$ am also aware that the data gathered in this study are confidential and anonymous with respect to my personal identity. My signature indicates that I agree to participate in this study.

Participant's Full Name: Participant's Signature:

Researcher's Name: Researcher's Signature:

Date 


\section{Appendix C: Written Debriefing}

\section{What are we trying to learn in this research?}

There are many different ways in which an individual can deal with a stressful event and even just the turmoil's of everyday life. These differences likely play a large role in who we are as a person as well as playing a key role in our successes. One of theses may be an ability to handle the pressures of being a varsity athlete. It has not been looked at whether or not different abilities in coping may actually play a role in separating successful high-level athletes. Specifically, varsity athletes may in fact be more resilient compared to a non-athlete. They may have either learned these skills through years of practice and hard work, or they may have been dealt a genetic hand that has allowed them to handle the pressure of being a varsity athlete.

The questionnaires and surveys are important in determining ones coping style and whether that person can be considered resilient. The questionnaires are also important at determining ones sense of self as well as assessing mood and well-being. In addition to the questionnaires, you were asked to provide a saliva sample. Genetic material (e.g., DNA) can be extracted from our saliva. Therefore we were interested in examining the relationships between your responses on some of the questionnaires (e.g., social identity and depressive symptoms) and certain genes (genes make up our DNA and may code for different traits such as, eye color). Multiple forms of the same gene are present within the population, wherein one or more forms of the gene might be related to our well-being (e.g., depression). You were asked to provide a saliva sample, genetic material (e.g., DNA) can be extracted from this saliva sample. Therefore we were interested in examining the relationships between your responses on some of the questionnaires (e.g., sense of well-being, depressive symptoms) and certain genes.

In this study, we are interested in examining the relationships between your level of resilience and overall sense of well-being. As well as, how some genetic factors might relate to various factors of resilience. We are also interested in examining the relationship between different forms of genes and how these may relate to an athletes success in dealing with a stressor.

What if I have questions later?

\section{Please contact}

Samantha Coates, Graduate Researcher 
Email: samantha.coates@carleton.ca

Dr. Hymie Anisman, Faculty Member

Phone: 613 520-3570, hymie anisman@,carleton.ca

Dr. Kim Matheson, Faculty Member

Phone: 613 520-2699, kim.matheson@carleton.ca

Ethical concerns: Dr. Shelley Brown, Chair of Carleton University Ethics Committee for Psychological Research, 613-520 2600 ext. 1505, shelley.brown@carleton.ca

Any other concerns: For any other concerns, please contact Dr. Joanne Pozzulo (Chair, Department of Psychology, 613-520-2600, ext. 1412, psychchair@carleton.ca) or Dr. John Stead (Chair, Department of Neuroscience, 613-520-2600 ext. 8774, john.stead@carleton.ca)

Is there anything that I can do if I found this experiment to be emotionally draining? Thank you very much for your participation in this study. If you feel any distress at the moment, from related to answering some of the personal questions during this study, you should be aware that these are legitimate feelings and it is understandable that thinking about past stressful experiences can induce feelings of distress. If you are experiencing any distress from completing these measures, please consult the resources below:

Carleton University Health and Counseling Services at: 613-520-6674,

Ottawa Distress Centre: (613) 238 1089, Web Site: www.dcottawa.on.ca.

Mental Health Crisis Line: within Ottawa (613) 722-6914, outside Ottawa 1-866-996-0991, Web Site: http://www.crisisline.ca/

\section{Want to know more about this subject? You can read the following studies by going to these links below:}

http://www.ncbi.nlm.nih.gov/pmc/articles/PMC2795557/

http://www.sciencemag.org/content/328/5984/1408.short 


\section{Appendix D: Background Information}

\section{Background Information}

The purpose of the following set of questions is to collect demographic information about various aspects of your life. Although some of the questions may seem unrelated to the present study (e.g. weight, height, religion, etc...) these factors may be important determinants of your health and well-being.

1. Sex: Female/ Male (please select one)

2. Age:

3. What is your first language?

If your first language is not English, how long have you been fluent in reading, writing and comprehension of the English language?

4. What is your ethnic/racial background? Please select the one that best applies to you.

Asian (e.g., Chinese, Japanese, Korean)

South Asian (e.g., East Indian, Pakistani, Punjabi, Tamil, Sri Lankan)

South East Asian (e.g., Cambodian, Indonesian, Laotian)

Arab/West Asian (e.g., Armenian, Egyptian, Iranian, Lebanese, Moroccan)

Black (e.g., African, Haitian, Jamaican, Somali)

Latin American/Hispanic

Aboriginal

White/Euro-Caucasian

Other (please specify):

5. What is your religious affiliation? Please select the one that best applies to you.

None-Atheist (e.g., belief that there is NO God)

None-Agnostic (e.g., belief that the existence of God cannot be known)

Protestant (e.g., United, Anglican, Baptist, Presbyterian, Lutheran, Pentecostal, 
Mennonite, “Christian”)

Catholic (e.g., Roman Catholic, Ukrainian Catholic)

Jewish

Muslim

Buddhist

Hindu

Sikh

Bahá'í

Other (please specify):

6. What is your current living arrangement? Please select the one that best applies to you.

Living in residence

Living off-campus

Living with parents

Living with spouse/significant other

Other (please specify)

7. What is your current relationship status? Please select the one that best applies to you.

Single, and not seeing anyone

Going out with someone

In a serious dating relationship

Have recently broken up ... Please specify how many weeks ago you broke up

Living with an intimate other

Engaged

Married

Separated/Divorced ....... Please specify how many months ago you separated

Widowed

8. Have you had or do you currently have any health related (i.e., medical) illnesses or physical conditions? Please select the one that best applies to you. 
NO, I don't

YES, I did but I no longer do

YES, I do

If YES, please specify illness/condition you had/have

If YES, please specify any current treatment you are receiving

9. Do you currently have a psychological disorder/condition (e.g. depression, anxiety, etc.)? NO, I don't

YES, I do

If YES, please specify disorder/condition

If YES, are you currently being treated for this disorder/condition?

NO, I'm not

YES I am

If YES, please specify treatment type (e.g. medications, therapy).

10. Have you ever in the past had a psychological disorder/condition (e.g. depression, anxiety, etc.) but no longer do?

NO, I haven't 
YES, I have

If YES, please specify the disorder/condition you had

11. In your opinion, how would you describe your health?

Poor

Fair

Good

Very good

Excellent

12. Are you on any of the following medications (please check all that apply)?

Anti-inflammatories (please specify)

Anti-depressants (please specify)

Anti-anxieties (please specify)

Allergy medication (please specify)

Other prescription drugs (please specify)

14. Are you an athlete?

YES

NO

15. Have you played organized sports (eg, high school or university varsity, city club, etc.)? YES NO

If yes, please list: 
16. Have you suffered a concussion in the last 12 months?

NO, I haven't

YES, I have

17. If so, how many have you had? 


\section{Appendix E: Ryff's Well-Being Scales}

\section{AUTONOMY}

\begin{tabular}{cccccc}
$\begin{array}{c}\text { Strongly } \\
\text { Disagree }\end{array}$ & $\begin{array}{c}\text { Moderately } \\
\text { Disagree }\end{array}$ & $\begin{array}{c}\text { Slightly } \\
\text { Disagree }\end{array}$ & $\begin{array}{c}\text { Slightly } \\
\text { Agree }\end{array}$ & $\begin{array}{c}\text { Moderately } \\
\text { Agree }\end{array}$ & $\begin{array}{c}\text { Strongly } \\
\text { Agree }\end{array}$ \\
\hline 1 & 2 & 3 & 4 & 5 & 6
\end{tabular}

1. Sometimes I change the way I act or think to be more like those around me.
2. I am not afraid to voice my opinions, even
123
$4 \quad 5$
6 when they are in opposition to the opinions of most people.

3. My decisions are not usually influenced by what everyone else is doing.

\begin{tabular}{|c|c|c|c|}
\hline $\begin{array}{l}\text { 4. I tend to worry about what other people think } \\
\text { of me. }\end{array}$ & 1 & 2 & 3 \\
\hline Being happy with myself is more important to & 1 & 2 & 3 \\
\hline
\end{tabular}
me than having others approve of me.

$\begin{aligned} & \text { 6. I tend to be influenced by people with strong } \\ & \text { opinions. }\end{aligned}$
$\begin{aligned} & \text { 7. People rarely talk me into doing things I don't } \\ & \text { want to do. }\end{aligned}$

$\begin{aligned} & \text { 8. It is more important to me to "fit in" with } \\ & \text { others than to stand alone on my principles. }\end{aligned}$
$\begin{aligned} & \text { ate } \\ & \text { and }\end{aligned}$

9. I have confidence in my opinions, even if they $\quad \begin{array}{llllllllll}1 & 2 & 3 & 4 & 5 & 6\end{array}$ are contrary to the general consensus.

$\begin{aligned} & \text { 10. It's difficult for me to voice my own opinions } \\ & \text { on controversial matters. }\end{aligned}$
a

11. I often change my mind about decisions if my $\quad \begin{array}{lllllllll}1 & 2 & 3 & 4 & 5 & 6\end{array}$ friends or family disagree.

$\begin{aligned} & \text { 12. I am not the kind of person who gives in to } \\ & \text { social pressures to think or act in certain ways. }\end{aligned}$
$\begin{aligned} & \text { 13. I am concerned about how other people } \\ & \text { evaluate the choices I have made in my life. }\end{aligned}$
$\begin{aligned} & \text { 14. I judge myself by what I think is important, } \\ & \text { not by the values of what others think is } \\ & \text { important. }\end{aligned}$




\section{PERSONAL GROWTH}

\begin{tabular}{cccccc}
$\begin{array}{c}\text { Strongly } \\
\text { Disagree }\end{array}$ & $\begin{array}{c}\text { Moderately } \\
\text { Disagree }\end{array}$ & $\begin{array}{c}\text { Slightly } \\
\text { Disagree }\end{array}$ & $\begin{array}{c}\text { Slightly } \\
\text { Agree }\end{array}$ & $\begin{array}{c}\text { Moderately } \\
\text { Agree }\end{array}$ & $\begin{array}{c}\text { Strongly } \\
\text { Agree }\end{array}$ \\
\hline 1 & 2 & 3 & 4 & 5 & 6
\end{tabular}

1. I am not interested in activities that will expand my horizons.

\begin{tabular}{|c|c|c|c|}
\hline $\begin{array}{l}\text { 2. In general, I feel that I continue to learn more } \\
\text { about myself as time goes by. }\end{array}$ & 1 & 2 & 3 \\
\hline $\begin{array}{l}\text { 3. I am the kind of person who likes to give new } \\
\text { things a try. }\end{array}$ & 1 & 2 & 3 \\
\hline
\end{tabular}

$\begin{aligned} & \text { 4. I don't want to try new ways of doing things - } \\ & \text { my life is fine the way it is. }\end{aligned}$
$\begin{aligned} & \text { 5. I think it is important to have new experiences } \\ & \text { that challenge how you think about yourself and } \\ & \text { the world. }\end{aligned}$.

6. When I think about it, I haven't really improved

12

3

4

5

6 much as a person over the years.

7. In my view, people of every age are able to continue growing and developing.

$\begin{array}{llllll}1 & 2 & 3 & 4 & 5 & 6\end{array}$

8. With time, I have gained a lot of insight about life $\quad \begin{array}{lllllll}1 & 2 & 3 & 4 & 5 & 6\end{array}$
that has made me a stronger, more capable person.

9. I have a sense that I have developed a lot as a $\quad \begin{array}{llllllll} & 1 & 2 & 3 & 4 & 5 & 6\end{array}$ person over time.

10. I do not enjoy being in new situations that require $\quad \begin{array}{llllll}1 & 2 & 3 & 4 & 5 & 6\end{array}$ me to change my old familiar was of doing things.

11. For me, life has been a continuous process of $\quad \begin{array}{llllllll} & 1 & 2 & 3 & 4 & 5 & 6\end{array}$ learning, changing, and growth.

$\begin{aligned} & \text { 12. I enjoy seeing how my views have changed and } \\ & \text { matured over the years. }\end{aligned}$

13. I gave up trying to make big improvements or $\quad \begin{array}{lllllll}1 & 2 & 3 & 4 & 5 & 6\end{array}$ changes in my life a long time ago.

14. There is truth to the saying you can’t teach an
old dog new tricks.




\section{PURPOSE IN LIFE}

\begin{tabular}{cccccc}
$\begin{array}{l}\text { Strongly } \\
\text { Disagree }\end{array}$ & $\begin{array}{c}\text { Moderately } \\
\text { Disagree }\end{array}$ & $\begin{array}{c}\text { Slightly } \\
\text { Disagree }\end{array}$ & $\begin{array}{c}\text { Slightly } \\
\text { Agree }\end{array}$ & $\begin{array}{c}\text { Moderately } \\
\text { Agree }\end{array}$ & $\begin{array}{c}\text { Strongly } \\
\text { Agree }\end{array}$ \\
\hline 1 & 2 & 3 & 4 & 5 & 6
\end{tabular}

1. I feel good when I think of what I've done in the $\quad \begin{array}{lllllll}1 & 2 & 3 & 4 & 5 & 6\end{array}$ past and what I hope to do in the future.

$\begin{aligned} & \text { 2. I live life one day at a time and don't really think } \\ & \text { about the future. }\end{aligned}$
$\begin{aligned} & \text { 3. I tend to focus on the present, because the future } \\ & \text { nearly always brings me problems. }\end{aligned}$

\begin{tabular}{|c|c|c|c|c|c|c|c|}
\hline 4. & I have a sense of direction and purpose in life. & 1 & 2 & 3 & 4 & 5 & 6 \\
\hline & $\begin{array}{l}\text { My daily activities often seem trivial and } \\
\text { ortant to me. }\end{array}$ & 1 & 2 & 3 & 4 & 5 & 6 \\
\hline
\end{tabular}

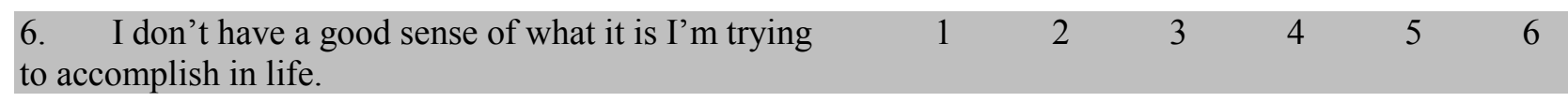

7. $\quad$ I used to set goals for myself, but that now seems $\quad \begin{array}{llllllll}1 & 2 & 3 & 4 & 5 & 6\end{array}$ like a waste of time.
8. I enjoy making plans for the future and working to make them a reality.
9. I am an active person in carrying out the plans I set for myself.

$\begin{array}{llllll}1 & 2 & 3 & 4 & 5 & 6 \\ 1 & 2 & 3 & 4 & 5 & 6\end{array}$

$\begin{aligned} & \text { 10. Some people wander aimlessly through life, but } \\ & \text { I am not one of them. }\end{aligned}$
al

11. I sometimes feel as if I've done all there is to do $\quad \begin{array}{lllllll}1 & 2 & 3 & 4 & 5 & 6\end{array}$ in life.
12. My aims in life have been more a source of satisfaction than frustration to me.
13. I find it satisfying to think about what I have accomplished in life.

$\begin{array}{llllll}1 & 2 & 3 & 4 & 5 & 6 \\ 1 & 2 & 3 & 4 & 5 & 6\end{array}$

14. In the final analysis, I'm not so sure that my life
adds up to much.


$\underline{\text { SELF-ACCEPTANCE }}$

\begin{tabular}{cccccc}
$\begin{array}{l}\text { Strongly } \\
\text { Disagree }\end{array}$ & $\begin{array}{c}\text { Moderately } \\
\text { Disagree }\end{array}$ & $\begin{array}{c}\text { Slightly } \\
\text { Disagree }\end{array}$ & $\begin{array}{c}\text { Slightly } \\
\text { Agree }\end{array}$ & $\begin{array}{c}\text { Moderately } \\
\text { Agree }\end{array}$ & $\begin{array}{c}\text { Strongly } \\
\text { Agree }\end{array}$ \\
\hline 1 & 2 & 3 & 4 & 5 & 6
\end{tabular}

1. When I look at the story of my life, I am pleased $\quad \begin{array}{lllllll}1 & 2 & 3 & 4 & 5 & 6\end{array}$ with how things have turned out.

$\begin{aligned} & \text { 2. In general, I feel confident and positive about } \\ & \text { myself. }\end{aligned}$
$\begin{aligned} & \text { 3. I feel like many of the people I know have } \\ & \text { gotten more out of life than I have. }\end{aligned}$

$\begin{aligned} & \text { 4. Given the opportunity, there are many things } \\ & \text { about myself I would change. }\end{aligned}$

5. I like most aspects of my personality. $\quad \begin{array}{llllllll} & 1 & 2 & 3 & 4 & 5 & 6\end{array}$

6. I made some mistakes in the past, but I feel that $\quad \begin{array}{lllllll}1 & 2 & 3 & 4 & 5 & 6\end{array}$ all in all everything has worked out for the best.

7. In many ways, I feel disappointed about my $\quad \begin{array}{lllllll}1 & 2 & 3 & 4 & 5 & 6\end{array}$ achievements in life.

8. For the most part, I am proud of who I am and $\quad \begin{array}{lllllll}1 & 2 & 3 & 4 & 5 & 6\end{array}$ the life I lead.

9. I envy many people for the lives they lead. $\quad \begin{array}{llllllll}1 & 2 & 3 & 4 & 5 & 6\end{array}$

10. My attitude about myself is probably not as $\quad \begin{array}{lllllll}1 & 2 & 3 & 4 & 5 & 6\end{array}$

positive as most people feel about themselves.

11. Many days I wake up feeling discouraged about $\quad \begin{array}{lllllll}1 & 2 & 3 & 4 & 5 & 6\end{array}$ how I have lived my life.

$\begin{aligned} & \text { 12. The past had its ups and downs, but in general, } \\ & \text { I wouldn't want to change it. }\end{aligned}$
$\begin{aligned} & \text { 13. When I compare myself to friends and } \\ & \text { acquaintances, it makes me feel good about } \\ & \text { who I am. }\end{aligned}$

$\begin{aligned} & \text { 14. Everyone has their weaknesses, but I seem to } \\ & \text { have more than my share. }\end{aligned}$
(n)




\section{Appendix F: Social Connected Scale}

\section{Social Connectedness Scale - Revised}

Instructions: The following are a number of statements that reflect various ways in which we view ourselves. Rate the degree to which you agree or disagree with each statement using the following scale $(1=$ Strongly Disagree and $6=$ Strongly Agree). There is no right or wrong answer. Do not spend too much time with any one statement and do not leave any unanswered.

\begin{tabular}{cccccc}
$\begin{array}{l}\text { Strongly } \\
\text { Disagree }\end{array}$ & $\begin{array}{c}\text { Moderately } \\
\text { Disagree }\end{array}$ & $\begin{array}{c}\text { Slightly } \\
\text { Disagree }\end{array}$ & $\begin{array}{c}\text { Slightly } \\
\text { Agree }\end{array}$ & $\begin{array}{c}\text { Moderately } \\
\text { Agree }\end{array}$ & $\begin{array}{c}\text { Strongly } \\
\text { Agree }\end{array}$ \\
\hline 1 & 2 & 3 & 4 & 5 & 6
\end{tabular}

1. I feel comfortable in the presence of strangers. $\quad \begin{array}{llllllll}1 & 2 & 3 & 4 & 5 & 6\end{array}$
2. I am in tune with the world.

1
2
3
4

$5 \quad 6$

3. Even among my friends, there is no sense of brother/sisterhood.

$\begin{array}{llllll}1 & 2 & 3 & 4 & 5 & 6\end{array}$

4. I fit in well in new situations.

$\begin{array}{llllll}1 & 2 & 3 & 4 & 5 & 6\end{array}$

5. I feel close to people.

$\begin{array}{llllll}1 & 2 & 3 & 4 & 5 & 6\end{array}$

6. I feel disconnected from the world around me.

12

3

4

5

6

7. Even around people I know, I don't feel that I really belong. $\begin{array}{llllll}1 & 2 & 3 & 4 & 5 & 6\end{array}$

8. I see people as friendly and approachable. 1

9. I feel like an outsider.

$\begin{array}{lllllll}1 & 2 & 3 & 4 & 5 & 6\end{array}$

10. I feel understood by the people I know.

$1-2$

3

56

11. I feel distant from people.

1

23

4

4

5

6

12. I am able to relate to my peers.

1

2

3

4

5

6

13. I have little sense of togetherness with 
my peers.

$\begin{array}{llllll}1 & 2 & 3 & 4 & 5 & 6\end{array}$

14. I find myself actively involved in

1

2

3

4

5

6 people's lives.

\begin{tabular}{cccccc}
$\begin{array}{l}\text { Strongly } \\
\text { Disagree }\end{array}$ & $\begin{array}{c}\text { Moderately } \\
\text { Disagree }\end{array}$ & $\begin{array}{c}\text { Slightly } \\
\text { Disagree }\end{array}$ & $\begin{array}{c}\text { Slightly } \\
\text { Agree }\end{array}$ & $\begin{array}{c}\text { Moderately } \\
\text { Agree }\end{array}$ & $\begin{array}{c}\text { Strongly } \\
\text { Agree }\end{array}$ \\
\hline 1 & 2 & 3 & 4 & 5 & 6
\end{tabular}

15. I catch myself losing a sense of connectedness with society.

$\begin{array}{lllllll}1 & 2 & 3 & 4 & 5 & 6\end{array}$

16. I am able to connect with other people.

$\begin{array}{llllll}1 & 2 & 3 & 4 & 5 & 6\end{array}$

17. I see myself as a loner.

$\begin{array}{llllll}1 & 2 & 3 & 4 & 5 & 6\end{array}$

18. I don't feel related to most people.

1

19. My friends feel like family.

12

4

$5 \quad 6$

20. I don't feel I participate with anyone or 1

2

3

3

4

5

6 any group. 


\section{Appendix G: Early Life Trauma Inventory}

\section{Early Life Trauma Inventory}

Most people have experienced a traumatic event at some point in their life. For this survey, we are interested in the types of traumatic events that you may have experienced, and how old you were when you experienced it. For each question, please indicate how many times you have experienced the event (if at all), and at what age range, by circling the appropriate number.

\section{Part 1. General Traumas}

1. Were you ever exposed to a life-threatening natural disaster?

\begin{tabular}{|c|c|c|c|c|c|c|}
\hline & $\begin{array}{c}0 \\
\text { Never }\end{array}$ & $\begin{array}{c}1 \\
\text { Once }\end{array}$ & $\begin{array}{c}2 \\
2-3 \\
\text { times }\end{array}$ & $\begin{array}{c}3 \\
4-5 \\
\text { times }\end{array}$ & $\begin{array}{c}4 \\
6-10 \\
\text { times }\end{array}$ & $\begin{array}{c}5 \\
\text { More than } 10 \\
\text { times }\end{array}$ \\
\hline \multicolumn{7}{|c|}{ 2. Were you involved in a serious accident? } \\
\hline & $\begin{array}{c}0 \\
\text { Never }\end{array}$ & $\begin{array}{c}1 \\
\text { Once }\end{array}$ & $\begin{array}{c}2 \\
2-3 \\
\text { times }\end{array}$ & $\begin{array}{c}3 \\
4-5 \\
\text { times }\end{array}$ & $\begin{array}{c} \\
6-10 \\
\text { times }\end{array}$ & $\begin{array}{c}5 \\
\text { More than } 10 \\
\text { times }\end{array}$ \\
\hline \multicolumn{7}{|c|}{ 3. Did you ever suffer a serious personal injury or illness? } \\
\hline & $\begin{array}{c}0 \\
\text { Never }\end{array}$ & $\begin{array}{c}1 \\
\text { Once }\end{array}$ & $\begin{array}{c}2 \\
2-3 \\
\text { times }\end{array}$ & $\begin{array}{c}3 \\
4-5 \\
\text { times }\end{array}$ & $\begin{array}{c}4 \\
6-10 \\
\text { times }\end{array}$ & $\begin{array}{c}5 \\
\text { More than } 10 \\
\text { times }\end{array}$ \\
\hline \multicolumn{7}{|c|}{ 4. Did you ever experience the death or serious illness of a parent or a primary caretaker? } \\
\hline & $\begin{array}{c}0 \\
\text { Never }\end{array}$ & $\begin{array}{c}1 \\
\text { Once }\end{array}$ & $\begin{array}{c}2 \\
2-3 \\
\text { times }\end{array}$ & $\begin{array}{c}3 \\
4-5 \\
\text { times }\end{array}$ & $\begin{array}{c}4 \\
6-10 \\
\text { times }\end{array}$ & $\begin{array}{l}5 \\
\text { More than } 10 \\
\text { times }\end{array}$ \\
\hline \multicolumn{7}{|c|}{ 5.Did you experience the divorce or separation of your parents? } \\
\hline & $\begin{array}{c}0 \\
\text { Never }\end{array}$ & $\begin{array}{c}1 \\
\text { Once }\end{array}$ & $\begin{array}{c}2 \\
2-3 \\
\text { times } \\
\end{array}$ & $\begin{array}{c}3 \\
4-5 \\
\text { times } \\
\end{array}$ & $\begin{array}{c} \\
6-10 \\
\text { times } \\
\end{array}$ & $\begin{array}{c}5 \\
\text { More than } 10 \\
\text { times }\end{array}$ \\
\hline \multicolumn{7}{|c|}{ 6.Did you experience the death or serious injury of a sibling? } \\
\hline & $\begin{array}{c}0 \\
\text { Never }\end{array}$ & $\begin{array}{c}1 \\
\text { Once }\end{array}$ & $\begin{array}{c}2 \\
2-3 \\
\text { times } \\
\end{array}$ & $\begin{array}{c}3 \\
4-5 \\
\text { times } \\
\end{array}$ & $\begin{array}{c} \\
6-10 \\
\text { times } \\
\end{array}$ & $\begin{array}{c}5 \\
\text { More than } 10 \\
\text { times }\end{array}$ \\
\hline \multicolumn{7}{|c|}{ 7.Did you ever experience the death or serious injury of a friend? } \\
\hline & $\begin{array}{c}0 \\
\text { Never }\end{array}$ & $\begin{array}{c}1 \\
\text { Once }\end{array}$ & $\begin{array}{c}2 \\
2-3 \\
\text { times } \\
\end{array}$ & $\begin{array}{c}3 \\
4-5 \\
\text { times } \\
\end{array}$ & $\begin{array}{c} \\
6-10 \\
\text { times } \\
\end{array}$ & $\begin{array}{c}5 \\
\text { More than } 10 \\
\text { times }\end{array}$ \\
\hline \multicolumn{7}{|c|}{ 8.Did you ever witness violence towards others, including family members? } \\
\hline & $\begin{array}{c}0 \\
\text { Never }\end{array}$ & $\begin{array}{c}1 \\
\text { Once }\end{array}$ & $\begin{array}{c}2 \\
2-3 \\
\text { times }\end{array}$ & $\begin{array}{c}3 \\
4-5 \\
\text { times }\end{array}$ & $\begin{array}{c}4 \\
6-10 \\
\text { times }\end{array}$ & $\begin{array}{c}5 \\
\text { More than } 10 \\
\text { times }\end{array}$ \\
\hline $\begin{array}{l}\text { 9.Did anyone in } \\
\text { "breakdown"? }\end{array}$ & ur fam & er suf & from m & lor ps & atric il & s or have a \\
\hline
\end{tabular}




\begin{tabular}{c|c|c|c|c|c} 
Never & Once & $\begin{array}{c}2-3 \\
\text { times }\end{array}$ & $\begin{array}{c}4-5 \\
\text { times }\end{array}$ & $\begin{array}{c}6-10 \\
\text { times }\end{array}$ & $\begin{array}{c}\text { More than 10 } \\
\text { times }\end{array}$
\end{tabular}

10. Did your parents or primary caretaker have a problem with alcoholism or drug abuse?

\begin{tabular}{|c|c|c|c|c|c|c|}
\hline & $\begin{array}{c}0 \\
\text { Never }\end{array}$ & $\begin{array}{c}1 \\
\text { Once }\end{array}$ & $\begin{array}{c}2 \\
2-3 \\
\text { times } \\
\end{array}$ & $\begin{array}{c}3 \\
4-5 \\
\text { times } \\
\end{array}$ & $\begin{array}{c}4 \\
6-10 \\
\text { times } \\
\end{array}$ & $\begin{array}{c}5 \\
\text { More than } 10 \\
\text { times }\end{array}$ \\
\hline \multicolumn{7}{|c|}{ 11. Did you ever see someone murdered? } \\
\hline & $\begin{array}{c}0 \\
\text { Never }\end{array}$ & $\begin{array}{c}1 \\
\text { Once }\end{array}$ & $\begin{array}{c}2 \\
2-3 \\
\text { times }\end{array}$ & $\begin{array}{c}3 \\
4-5 \\
\text { times }\end{array}$ & $\begin{array}{c} \\
6-10 \\
\text { times }\end{array}$ & $\begin{array}{c}5 \\
\text { More than } 10 \\
\text { times }\end{array}$ \\
\hline
\end{tabular}

\section{Part 2: Physical Punishment}

1. Were you ever slapped in the face with an open hand?

\begin{tabular}{|c|c|c|c|c|c|c|}
\hline & $\begin{array}{c}0 \\
\text { Never }\end{array}$ & $\begin{array}{c}1 \\
\text { Once }\end{array}$ & $\begin{array}{c}2 \\
2-3 \\
\text { times }\end{array}$ & $\begin{array}{c}3 \\
4-5 \\
\text { times }\end{array}$ & $\begin{array}{c}4 \\
6-10 \\
\text { times } \\
\end{array}$ & $\begin{array}{c}5 \\
\text { More than } 10 \\
\text { times }\end{array}$ \\
\hline \multicolumn{7}{|c|}{ 2. Were you ever burned with hot water, a cigarette or something else? } \\
\hline & $\begin{array}{c}0 \\
\text { Never }\end{array}$ & $\begin{array}{c}1 \\
\text { Once }\end{array}$ & $\begin{array}{c}2 \\
2-3 \\
\text { times } \\
\end{array}$ & $\begin{array}{c}3 \\
4-5 \\
\text { times } \\
\end{array}$ & $\begin{array}{c} \\
6-10 \\
\text { times } \\
\end{array}$ & $\begin{array}{c} \\
\text { More than } 10 \\
\text { times }\end{array}$ \\
\hline \multicolumn{7}{|c|}{ 3.Were you ever punched or kicked? } \\
\hline & $\begin{array}{c}0 \\
\text { Never }\end{array}$ & $\begin{array}{c}1 \\
\text { Once }\end{array}$ & $\begin{array}{c}2 \\
2-3 \\
\text { times } \\
\end{array}$ & $\begin{array}{c}3 \\
4-5 \\
\text { times } \\
\end{array}$ & $\begin{array}{c}4 \\
6-10 \\
\text { times } \\
\end{array}$ & $\begin{array}{c}5 \\
\text { More than } 10 \\
\text { times }\end{array}$ \\
\hline \multicolumn{7}{|c|}{ 4. Were you ever hit with an object that was thrown at you? } \\
\hline & $\begin{array}{c}0 \\
\text { Never }\end{array}$ & $\begin{array}{c}1 \\
\text { Once }\end{array}$ & $\begin{array}{c}2 \\
2-3 \\
\text { times } \\
\end{array}$ & $\begin{array}{c}3 \\
4-5 \\
\text { times } \\
\end{array}$ & $\begin{array}{c}4 \\
6-10 \\
\text { times } \\
\end{array}$ & $\begin{array}{c}5 \\
\text { More than } 10 \\
\text { times }\end{array}$ \\
\hline \multicolumn{7}{|c|}{ 5.Were you ever pushed or shoved? } \\
\hline & $\begin{array}{c}0 \\
\text { Never }\end{array}$ & $\begin{array}{c}1 \\
\text { Once }\end{array}$ & $\begin{array}{c}2 \\
2-3 \\
\text { times }\end{array}$ & $\begin{array}{c}3 \\
4-5 \\
\text { times }\end{array}$ & $\begin{array}{c}4 \\
6-10 \\
\text { times }\end{array}$ & $\begin{array}{c}5 \\
\text { More than } 10 \\
\text { times }\end{array}$ \\
\hline
\end{tabular}

\section{Part 3: Emotional Abuse}

1. Were you often put down or ridiculed?

\begin{tabular}{c|c|c|c|c|c|c}
\hline & 0 & 1 & 2 & 3 & 4 & 5 \\
& Never & Once & $\begin{array}{c}2-3 \\
\text { times }\end{array}$ & $\begin{array}{c}4-5 \\
\text { times }\end{array}$ & $\begin{array}{c}6-10 \\
\text { times }\end{array}$ & $\begin{array}{c}\text { More than 10 } \\
\text { times }\end{array}$ \\
\hline
\end{tabular}

2. Were you often ignored or made to feel that you didn't count?

\begin{tabular}{c|c|c|c|c|c|c}
\hline & 0 & 1 & 2 & 3 & 4 & 5 \\
& Never & Once & $\begin{array}{c}2-3 \\
\text { times }\end{array}$ & $\begin{array}{c}4-5 \\
\text { times }\end{array}$ & $\begin{array}{c}6-10 \\
\text { times }\end{array}$ & $\begin{array}{c}\text { More than 10 } \\
\text { times }\end{array}$ \\
\hline
\end{tabular}

3. Were you often told you were no good? 


\begin{tabular}{l|c|c|c|c|c|c} 
& $\begin{array}{c}0 \\
\text { Never }\end{array}$ & $\begin{array}{c}1 \\
\text { Once }\end{array}$ & $\begin{array}{c}2 \\
2-3 \\
\text { times }\end{array}$ & $\begin{array}{c}3 \\
4-5 \\
\text { times }\end{array}$ & $\begin{array}{c}4 \\
6-10 \\
\text { times }\end{array}$ & $\begin{array}{c}\text { More than } 10 \\
\text { times }\end{array}$ \\
\hline \begin{tabular}{l} 
4. Most of the time were you treated in a cold, uncaring way or made to feel like you \\
were not loved? \\
\hline
\end{tabular}$\quad$\begin{tabular}{c|c|c|c|c|c}
0 \\
Never
\end{tabular} & $\begin{array}{c}1 \\
\text { Once }\end{array}$ & $\begin{array}{c}2-3 \\
\text { times }\end{array}$ & $\begin{array}{c}3 \\
\text { times }\end{array}$ & $\begin{array}{c}4 \\
6-10 \\
\text { times }\end{array}$ & $\begin{array}{c}\text { More than } 10 \\
\text { times }\end{array}$ \\
\hline \\
\hline
\end{tabular}

\section{Part 4: Sexual Events}

1. Were you ever touched in an intimate or private part of your body (e.g. breast, thighs, genitals) in a way that surprised you or made you feel uncomfortable?

\begin{tabular}{|c|c|c|c|c|c|c|}
\hline & $\begin{array}{c}0 \\
\text { Never }\end{array}$ & $\begin{array}{c}1 \\
\text { Once }\end{array}$ & $\begin{array}{c}2 \\
2-3 \\
\text { times }\end{array}$ & $\begin{array}{c}3 \\
4-5 \\
\text { times } \\
\end{array}$ & $\begin{array}{c} \\
6-10 \\
\text { times } \\
\end{array}$ & $\begin{array}{c}5 \\
\text { More than } 10 \\
\text { times }\end{array}$ \\
\hline \multicolumn{7}{|c|}{ 2. Did you ever experience someone rubbing their genitals against you? } \\
\hline & $\begin{array}{c}0 \\
\text { Never }\end{array}$ & $\begin{array}{c}1 \\
\text { Once }\end{array}$ & $\begin{array}{c}2 \\
2-3 \\
\text { times }\end{array}$ & $\begin{array}{c}3 \\
4-5 \\
\text { times }\end{array}$ & $\begin{array}{c}4 \\
6-10 \\
\text { times }\end{array}$ & $\begin{array}{c}5 \\
\text { More than } 10 \\
\text { times }\end{array}$ \\
\hline
\end{tabular}

3. Were you ever forced or coerced to touch another person in an intimate or private part of their body?

\begin{tabular}{c|c|c|c|c|c|c}
\hline & 0 & 1 & 2 & 3 & 4 & 5 \\
& Never & Once & $\begin{array}{c}2-3 \\
\text { times }\end{array}$ & $\begin{array}{c}4-5 \\
\text { times }\end{array}$ & $\begin{array}{c}6-10 \\
\text { times }\end{array}$ & $\begin{array}{c}\text { More than 10 } \\
\text { times }\end{array}$ \\
\hline
\end{tabular}

4. Did anyone ever have genital sex with you against your will?

\begin{tabular}{c|c|c|c|c|c|c}
\hline & $\begin{array}{c}0 \\
\text { Never }\end{array}$ & $\begin{array}{c}1 \\
\text { Once }\end{array}$ & $\begin{array}{c}2 \\
2-3 \\
\text { times }\end{array}$ & $\begin{array}{c}4 \\
4-5 \\
\text { times }\end{array}$ & $\begin{array}{c}4 \\
6-10 \\
\text { times }\end{array}$ & $\begin{array}{c}\text { More than 10 } \\
\text { times }\end{array}$ \\
\hline \\
\hline
\end{tabular}

6. Were you ever forced or coerced to kiss someone in a sexual rather than an affectionate way?

\begin{tabular}{|c|c|c|c|c|c|}
\hline 0 & 1 & 2 & 3 & 4 & 5 \\
Never & Once & $2-3$ & $4-5$ & $6-10$ & More than 10 \\
& & times & times & times & times
\end{tabular}




\section{Appendix H: Beck Depression Inventory}

\section{Beck Depression Inventory (BDI)- 21 item scale}

On this questionnaire are groups of statements. Please read the entire group of statements in each category. Then pick out ONE statement in that group which best describes the way you feel. Check off the number beside the statement you have chosen.

1. _ $0 \quad=\mathrm{I}$ do not feel sad

1 = I feel sad or blue

$2 \mathrm{a}=\mathrm{I}$ am blue or sad all of the time and I can't snap out of it

$2 \mathrm{~b}=\mathrm{I}$ am so sad or unhappy that it is very painful

3 _ I I am so sad or unhappy that I can't stand it

2. $\quad 0=$ I am not particularly pessimistic or discouraged about the future

$1=\mathrm{I}$ feel discouraged about the future

$2 \mathrm{a}=\mathrm{I}$ feel I have nothing to look forward to

$2 \mathrm{~b}=\mathrm{I}$ feel I won't ever get over my troubles

3 - I feel that the future is hopeless and things cannot improve

3. $\quad 0=\mathrm{I}$ do not feel like a failure

1 = I feel I have failed more than the average person

$2 \mathrm{a}=\mathrm{I}$ feel I have accomplished very little that is worthwhile or that means anything

$2 \mathrm{~b}=$ As I look back on my life, all I can see is a lot of failures

3 = I feel I am a complete failure as a person

4. $\_$_ 0 I am not particularly dissatisfied

$1 \mathrm{a}=\mathrm{I}$ feel bored most of the time

$1 \mathrm{~b}=\mathrm{I}$ don't enjoy things the way I used to

2 = I don't get satisfaction out of anything anymore 
$3=$ I am dissatisfied with everything

5. __ $0=$ I don't feel particularly guilty

1 _ 1 I feel bad or unworthy a good part of the time

$2 \mathrm{a}=\mathrm{I}$ feel quite guilty

$2 \mathrm{~b}=\mathrm{I}$ feel bad or unworthy practically all of the time now

$3=$ I feel as though I am very bad or worthless

6. $\_$_ $0=$ I don't feel I am being punished

1 _ I I have a feeling that something bad may happen to me

2 _ $=$ I feel I am being punished or will be punished

$3 \mathrm{a}=\mathrm{I}$ feel I deserve to be punished

$3 b=$ I want to be punished

7. $\_$_ 0 I don't feel disappointed in myself

$1 \mathrm{a}=\mathrm{I}$ am disappointed in myself

$1 \mathrm{~b}=\mathrm{I}$ don't like myself

$2=$ I am disgusted with myself

3 - I hate myself

8. $\quad 0 \quad=$ I do not feel I am any worse than anybody else

$1=\mathrm{I}$ am very critical of myself for my weaknesses or mistakes

$2 \mathrm{a}=$ I blame myself for everything that goes wrong

$2 \mathrm{~b}=\mathrm{I}$ feel I have many bad faults

$9 \_0=$ I don't have thoughts of harming myself

1 = I have thoughts of harming myself but I would not carry them out

$2 \mathrm{a}=$ I feel I would be better off dead

$2 \mathrm{~b}=\mathrm{I}$ have definite plans about committing suicide 
$2 \mathrm{c}=\mathrm{I}$ feel my family would be better off if I were dead

3 = I would kill myself if I could

10. _ $0=$ I don't cry anymore than usual

$1=$ I cry more now than I used to

$2=$ I cry all the time now. I can't stop it

$3=$ I used to be able to cry but now I can't cry at all even though I want to

11. $0=\mathrm{I}$ am no more irritable than usual

$1=$ I am more irritable than usual

2 _ $=$ I am much more irritable than usual

$3=$ I am irritable all the time

12. _ $0=$ I have not lost interest in other people

$1=\mathrm{I}$ am less interested in other people than I used to be

2 = I have lost most of my interest in other people and I have little feeling for them

3 _ I have lost all my interest in other people and don't care about them at all

13. _ $0=$ I make decisions about as well as ever

$1=\mathrm{I}$ am less sure of myself now and try to put off making decisions

$2=$ I can't make decisions anymore without help

3 = I can't make decisions at all anymore

14. _ $0=$ I don't feel I look any worse than I used to

$1=\mathrm{I}$ am worried that I am looking old or unattractive

$2=\mathrm{I}$ feel that there are permanent changes in my appearance and they make me look unattractive

$3=$ I feel that I am ugly or repulsive looking 
15. _ 0 = I can work about as well as before

$1 \mathrm{a}=$ It takes extra effort to get started at doing something

$1 \mathrm{~b}=\mathrm{I}$ don't work as well as I used to

2 _ 2 I have to push myself very hard to do anything

3 = I can't do any work at all

16. _ $0=$ I can sleep as well as usual

$1=$ I wake up more tired in the morning than I used to

2 _ $=$ I wake up 1-2 hours earlier than usual and find it hard to get back to sleep

3 = I wake up early every day and can't get more than 5 hours sleep

17. $\quad 0=\mathrm{I}$ don’t get anymore tired than usual

$1=$ I get tired more easily than I used to

2 _ $=$ I get tired from doing anything

3 = I get too tired to do anything

18. _ $0=$ My appetite is no worse than usual

1 = My appetite is not as good as it used to be

2 - My appetite is much worse now

3 = I have no appetite at all any more

19. _ $0=$ I haven't lost much weight, if any, lately

$1=$ I have lost more than 5 pounds

2 = I have lost more than 10 pounds

3 = I have lost more than 15 pounds

20. $\quad 0=\mathrm{I}$ am no more concerned about my health than usual

$1=\mathrm{I}$ am concerned about aches and pains or upset stomach or constipation or other unpleasant feelings in my body 
2 I I am so concerned with how I feel or what I feel that it's hard to think of much else $3=\mathrm{I}$ am completely absorbed in what I feel

21. _ 0 = I have not noticed any recent change in my interest in sex

$1=\mathrm{I}$ am less interested in sex than I used to be $2=\mathrm{I}$ am much less interested in sex now

3 = I have lost interest in sex completely 